Doporučené postupy vycházejí ze soudobých poznatků lékařské vědy a považují se za postupy lege artis. Jde však o doporučení, nikoli předpisy, proto je nutný individuální přístup ke každému nemocnému. Ošetřující lékař může použít jiný postup, musí však v dokumentaci řádně zdůvodnit, proč se od doporučeného postupu odchýlil.

\title{
Fibrilace síní
}

Doporučený diagnostický a léčebný postup České kardiologické společnosti vypracovaný Pracovní skupinou arytmie a trvalé kardiostimulace

\author{
Autorský kolektiv: Robert Čihák1, Petr Heinc², Luděk Haman³, Martin Fiala, Petr Neužil ${ }^{5}$, Ondřej Toman ${ }^{6}$ \\ ${ }^{1}$ Klinika kardiologie, IKEM, Praha; ${ }^{2}$ I. interní klinika FN, Olomouc; ${ }^{3}$. interní klinika FN, Hradec Králové; ${ }^{4}$ Nemocnice Podlesí, Trinec; \\ ${ }^{5}$ Kardiocentrum, Nemocnice Na Homolce, Praha; ${ }^{6}$ Interní kardiologická klinika LF MU a FN, Brno
}

Adresa: MUDr. Robert Čihák, CSc., Klinika kardiologie, IKEM, Vídeňská 1958/9, 14021 Praha 4, e-mail: robert.cihak@ikem.cz

\section{1 Úvod}

Fibrilace síní (FS) je nejčastější setrvalou poruchou srdečního rytmu. Je diagnostikována u 1-2\% populace a výskyt stále roste. Provází ji zvýšená morbidita a mortalita, např́klad riziko cévní mozkové př́hody (CMP) je pětinásobné. To je důvodem stálého hledání optimální léčby pacientů s FS.

Doporučené postupy u pacientů s fibrilací síní byly publikovány v letech 2001 a 2006 ${ }^{1}$. Šlo o společná guidelines Evropské kardiologické společnosti (European Society of Cardiology, ECS) a amerických kardiologických asociací (AHA, ACC). Od té doby bylo prezentováno mnoho důležitých studií a vyvstala potřeba inovace. V srpnu 2010 byla zveřejněna kompletně přepracovaná nová evropská guidelines, vypracovaná jen Evropskou kardiologickou společností. ${ }^{2}$ Pro americký kontinent bylo na přelomu roku 2010-2011 zahájeno vydávání zatím jen velmi mírných aktualizací guidelines z roku 2006.,3 Další aktualizace budou patrně následovat podle průběhu schvalování nových léčebných postupů.

V České republice byla doporučení pro léčbu pacientů s fibrilací síní oponována na podzim $2003 .{ }^{5}$ Vzhledem $\mathrm{k}$ výraznému rozvoji léčebných metod nyní předkládáme novou verzi. Ta vychází zejména $\mathrm{z}$ evropských guidelines, ale přihlíži i $\mathrm{k}$ americkým aktualizacím a dalším zdrojům a studiím, které byly od prezentace evropských guidelines zveřejněny. Protože vývoj poznatků o fibrilaci síní je velmi dynamický, zejména v oblasti prevence tromboembolických příhod, lze předpokládat nutnost častějších inovací, patrně také formou doplňků.

\section{Definice, klasifikace, etiologie \\ 2.1 Definice fibrilace síní}

Jde o supraventrikulární arytmii charakterizovanou rychlou nekoordinovanou akcí síní. Na elektrokardiografickém záznamu nejsou patrny jasné vlny $\mathrm{P}$, někdy lze rozpoznat vlnění izoelektrické linie či rychlé fibrilační vlnky o frekvenci $>300 / \mathrm{min}$, a to zejména ve svodu $V_{1}$. Vlnky se mohou místy do určité míry zpravidelnit a zvětšit (tzv. hrubovlnná FS, zaměňovaná někdy za flutter síní či síňové tachykardie nebo nesprávně popisovaná jako fibrilo-flutter síní). Frekvence práce komor je závislá na převodních vlastnostech AV uzlu, prrítomnosti akcesorních drah, tonu sympatiku a vagu a velmi podstatně také na vlivu medikace. U neléčeného nemocného je zcela nepravidelný interval R-R („absolutní“ arytmie) a frekvence komor 100-160/min. Někdy je akce komor relativně vyrovnaná a kolísá v malém rozmezí, jindy je zcela nevyrovnaná. Při vyšším převodu na komory mohou být některé nebo všechny komplexy QRS aberované. Pravidelná akce komor je typická pro atrioventrikulární blokádu a náhradní junkční či komorový rytmus, aktivní náhradní rytmus a přechod fibrilace síní v jinou arytmii. Fibrilaci síní může maskovat také pravidelný stimulovaný rytmus. Jako fibrilace síní se označují epizody trvající $\geq 30$ sekund, 
za určitých okolností mohou mít význam i arytmie kratší, naopak klinický význam mívají většinou až delší epizody. ${ }^{2,6}$

Pro stanovení diagnózy fibrilace síní jsou tedy důležitá následující kritéria:

> nepravidelná akce komor s nepravidelnými intervaly $\mathrm{R}-\mathrm{R}$,

> absence jednoznačných a pravidelných vln $\mathrm{P}$, fibrilační vlnky jsou nejlépe hodnotitelné ve svodu $\mathrm{V}_{1}$,

frekvence fibrilačních vlnek > 300/min (<200 ms),

> arytmie trvá minimálně 30 sekund.

\subsection{Jiné arytmie, které se vyskytují s fibrilací síní}

Fibrilace síní se může vyskytovat samostatně, nebo může být spojena s jinými supraventrikulárními arytmiemi. Častý je společný výskyt s flutterem síní, kdy se obě arytmie u téhož nemocného mohou střídat či přecházet jedna $\mathrm{v}$ druhou. Při léčbě antiarytmiky skupiny IC či III se síně mohou stabilizovat jen do určité míry a místo fibrilace síní dochází k atakám flutteru („flutter IC či III“). Typický flutter síní má definovaný reentry okruh kolem anulu trikuspidální chlopně. Šiŕí se nejčastěji proti směru hodinových ručiček (counterclockwise flutter), je charakteristický aktivitou síní připomínající v EKG zuby pily ve svodech II, III, aVF. Při opačném směru šírení (clockwise flutter) jsou vlny P ve svodech II, III, aVF pozitivní. Frekvence síní u neléčeného flutteru bývá obvykle 240-300/min, převod pak obvykle $2: 1$ nebo obecně $\mathrm{n}: 1$. K ozřejmení síňové aktivity u arytmie s rychlou odpovědí komor lze využít farmaka či manévry zpomalující vedení v atrioventrikulárním (AV) uzlu (masáž karotického sinu, Valsalvův manévr, i.v. adenosin). Vzácně může při tzv. deblokaci flutteru dojít $\mathrm{k}$ převodu $1: 1$. Při reentry okruhu mimo trikuspidální anulus (např. kolem mitrálního anulu, jizvy nebo fibrotického ložiska v síních) hovoříme o atypickém flutteru. Fibrilace síní může být spojena i se síňovými tachykardiemi, s AV nodální a AV reentry tachykardií: tyto tachykardie ji dokonce mohou spouštět. Velmi často lze u pacientů s paroxysmální fibrilací síní při EKG monitoraci zachytit četné supraventrikulární extrasystoly nebo jejich salvy, které fibrilace síní spouštějí.

\subsection{Klasifikace fibrilací síní}

Fibrilace síní můžeme klasifikovat podle řady hledisek. Jako izolovaná („lone“) fibrilace síní je označována arytmie bez přítomného kardiovaskulárního onemocnění. Pojem idiopatická fibrilace síní vyjadřuje spíše skutečnost, že jsme nenalezli jasnou vyvolávající prríčinu či známé onemocnění. V literatuře se lze často setkat s pojmem „nechlopenni““ („nonvalvular“) fibrilace síní, která popisuje arytmie bez př́tomnosti závažné chlopenní vady či náhrady a má význam v posuzování rizika tromboembolie. Jako sekundární fibrilace síní popisujeme př́hody vzniklé při infarktu myokardu, po kardiochirurgických operacích, při perikarditidě či myokarditidě, plicní embolii, tyreopatii, pneumonii a dalších onemocněních. V současnosti se nejčastěji doporučuje dělení na fibrilace síní jako první dokumentovanou ataku, paroxysmální, perzistující, dlouhodobě perzistující a permanentní fibrilace síní (tabulka 1).
Tab. 1 Typy fibrilace síní

\begin{tabular}{ll}
\hline Typ fibrilace síní & \\
\hline Poprvé diagnostikovaná & Prvně diagnostikovaná, nezávisle na trvání \\
\hline Paroxysmální & $\begin{array}{l}\text { Epizody končí spontánně, obvykle } \\
\text { do } 48 \text { hodin }\end{array}$ \\
\hline Perzistující & $\begin{array}{l}\text { Epizody delší než } 7 \text { dní či vyžadující } \\
\text { kardioverzi }\end{array}$ \\
\hline Perzistující dlouhodobě & $\begin{array}{l}\text { Trvání déle než } 1 \text { rok, ale stále plánována } \\
\text { obnova sinusového rytmu (např. ablací) }\end{array}$ \\
\hline Permanentní & $\begin{array}{l}\text { Dlouhodobé trvání FS, akceptovaná } \\
\text { lékařem i pacientem jako setrvalá }\end{array}$ \\
\hline
\end{tabular}

Poprvé zjištěná epizoda fibrilace síní u daného pacienta může být symptomatická i asymptomatická, spontánně končící i přetrvávající. Může jít o jedinou epizodu, nebo může v budoucnu recidivovat. Jako recidivující fibrilace síní se označuje př́ípad, kdy má pacient dokumentovány alespoň dvě ataky. Paroxysmální fibrilace síní je pojmenování pro recidivy FS, které končí spontánně. Označujeme tak epizody trvající alespoň 30 sekund, i když za určitých okolností mají význam i epizody kratší. Pokud fibrilace přetrvává déle než sedm dní, hovoříme o perzistující fibrilaci síní. Epizody obvykle končí až po provedené kardioverzi, at' už medikamentózní, nebo po elektrokardioverzi. U jednoho pacienta se mohou současně vyskytovat kratší paroxysmy fibrilace síní i epizody perzistující formy. Dlouhodobě perzistující fibrilace síní trvá déle než rok, ale stále zvažujeme kontrolu rytmu. Permanentní fibrilace síní většinou přetrvává nebo časně recidivuje i po kardioverzích a přijali jsme ji již jako trvalý srdeční rytmus pacienta. ${ }^{2}$

Při posuzování FS u individuálního nemocného však musíme přihlédnout $\mathrm{k}$ řadě jiných faktorů, jako je symptomatologie, hemodynamický vliv, trvání fibrilace či frekvence atak, věk pacienta, přítomnost a závažnost kardiálního onemocnění a dalších přidružených chorob.

Fibrilace síní obvykle začíná jako paroxysmální, v průběhu let $\mathrm{u}$ většiny pacientů progreduje do setrvalejších forem. K této progresi nedochází pouze u minimálního počtu pacientů (2-3 \%). ${ }^{7}$ Nezávislými prediktory progrese fibrilace síní jsou srdeční selhání, věk nad 75 let, předchozí CMP nebo transitorní ischemická ataka (TIA), chronická obstrukční plicní nemoc a hypertenze (tzv. skóre HATCH ${ }^{8}$ ). U nově zjištěné fibrilace síní je riziko rekurence $\mathrm{v}$ prvním roce $10 \%$, v dalších letech $5 \%$. Asymptomatické záchvaty fibrilace síní jsou četné i u symptomatických pacientů.

\subsection{Příčiny a rizikové faktory vzniku fibrilace síní}

Výskyt přibývá $s$ věkem, patrně v důsledku fibrotizace myokardu a ztráty myocytů (tabulka 2). Z kardiovaskulárních onemocnění je nejčastějším rizikovým faktorem hypertenze. Jak s věkem, tak i s prrítomností hypertenze také stoupá riziko tromboembolických komplikací. Další příčinou FS může být srdeční selhání. Chlopenní vady lze zjistit až u $30 \%$ pacientů s fibrilací síní. Častěji se s ní setkáme u kardiomyopatií, at již jde o primární onemocnění s porušenými elektrofyziologickými vlastnostmi při různých 
Tab. 2 Remodelační změny v síních, spojené se vznikem a udržováním fibrilace síní

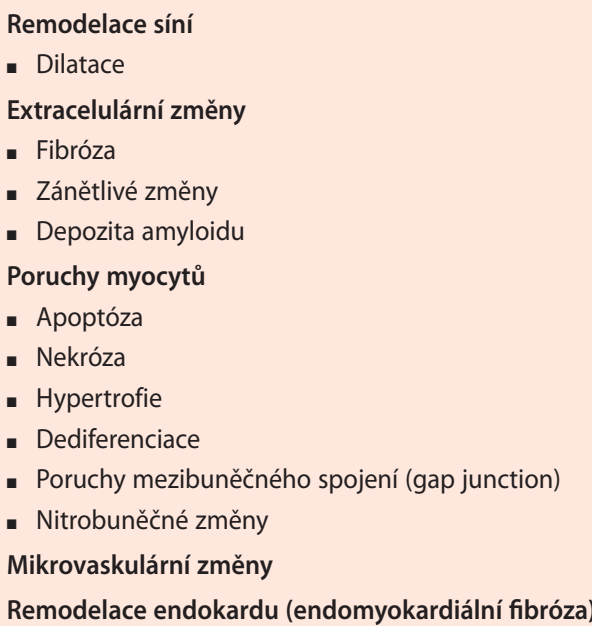

mutacích elektrických kanálů, nebo o různé myopatie. U 10-15 \% nemocných lze zjistit defekt síňového septa, který je také spojen s rizikem CMP. Ischemická choroba srdeční s postižením koronárních tepen je přítomna u $20 \%$ pacientů s fibrilací síní. Z endokrinních chorob je nejčastější porucha funkce štítné žlázy, at už ve formě manifestní, nebo subklinické. Četnost výskytu dysfunkce štítné žlázy zvyšuje antiarytmická medikace amiodaronem. Až $25 \%$ pacientů s fibrilací síní je obézních - s tím je částečně spojen i výskyt diabetes mellitus, který představuje riziko pro vznik fibrilace síní i tromboembolismu. Z dalších rizikových faktorů je důležitá chronická obstrukční plicní nemoc, spánková apnoe a chronické onemocnění ledvin. ${ }^{9,10}$

Existuje také genetická predispozice k fibrilaci síní. Vyskytuje se častěji u syndromu dlouhého i krátkého intervalu QT, syndromu Brugadových, hypertrofické kardiomyopatie a dalších chorob s familiárním výskytem. Kromě toho existuje familiární výskyt i samotné izolované fibrilace síní - byly popsány rodiny s vyšším výskytem této arytmie.

\subsection{Patofyziologie a mechanismus vzniku}

\subsubsection{Anatomický substrát}

Fibrilace síní vzniká na podkladě strukturálně změněných, ale i poměrně zdravých srdečních síní. Strukturální změny síní jsou geometrické (dilatace) a anatomicko-histologické (vazivová přestavba, ukládání amyloidu apod.). ${ }^{11-14}$ Dominantním srdečním oddílem pro vznik fibrilace je levá sín, účast pravé síně je méně významná. Strukturální změny síní vznikají v důsledku primárních kardiovaskulárních onemocnění a stavů a současně jsou navozovány a zhoršovány vlastní fibrilací. Tato tzv. arytmií indukovaná remodelace se děje časně na elektrické úrovni a později i na strukturální a mechanické úrovni. ${ }^{15,16}$ Fibrilace síní tak uzavírá bludný kruh, ve kterém sama sebe dále zhoršuje. Čím déle trvá, tím více jsou strukturální změny zpravidla vyjádřeny. Všeobecně platí, že změny jsou výraznější u paroxysmální formy než u perzistentní, existují však časté výjimky. ${ }^{20,21}$
Pokročilá remodelace siní je př́činou nižši úspěšnosti léčby, konkrétně kontroly rytmu u fibrilace síní, a to farmakologické i nefarmakologické (např. kardioverze, ablace).

Obnovení sinusového rytmu bývá spojeno s úplnou nebo jen částečnou úpravou těchto změn, $\mathrm{tj}$. s tzv. reverzní remodelací. ${ }^{17-19}$ Některé změny, jako fibróza a jizvení v myokardu, však reverzibilní nejsou.

\subsubsection{Mechanismus vzniku}

Na mechanismu vzniku fibrilace síní se podílí ektopická i reentry aktivita. U žádné formy fibrilace síní neplatí uniformní mechanismus, i když ektopie je častější u paroxysmálních forem a reentry u forem perzistujících. Spouštěčem i udržovacím faktorem může být pokračující ektopická aktivita. Ektopická ložiska se většinou nacházejí v oblasti ústí plicích žil, ale také např. v koronárním sinu, Marshallově ligamentu, ústí horní duté žíly nebo ve volné stěně levé i pravé síně. Kromě toho může být fibrilace síní udržována setrvalou aktivací lokalizovaných reentry okruhů nebo velkých makro-reentry okruhů. Spektrum mechanismů vzniku fibrilace síní se tedy může individuálně pohybovat od izolovaného ektopického fokusu z plicní źíly až po kombinaci všech uvedených zdrojů. Dále se na jejím spouštění a udržování podílí autonomní nervový systém, a to prostřednictvím perikardiálních autonomních ganglií.

Fibrilace síní se často vyskytuje u pacientů se srdečním selháním. Mechanismem jsou zde strukturální změny, zejména vznik jizev a fibrotizace myokardu, dilatace a přetížení síní i vliv zvýšené neurohumorální regulace. Rychlá frekvence síní však sama o sobě zhoršuje jejich funkci a může vést $\mathrm{k}$ poklesu funkce levé komory (tzv. tachykardická kardiomyopatie). Kromě frekvence má svůj vliv i nepravidelná akce komor, př́padně medikace. Studie po ablaci AV junkce i po selektivní ablaci pro fibrilaci síní ukázaly, že část těchto změn je reverzibilních. Po ablaci se zlepší či v některých př́padech zcela normalizuje funkce levé komory. Fibrilace siní tedy může být následkem i príčcinou srdečního selhání.

Zvýšené riziko tromboembolie u fibrilace síní se klasicky vysvětluje stagnací krve ve změněné levé síni a jejím oušku. Kromě toho je pravděpodobné, že fibrilace síní sama navozuje určitý hyperkoagulační stav. Současně je i markerem jiných chorob predisponujících k CMP, jako jsou ateroskleróza aorty, cerebrovaskulární onemocnění a kalcifikace mitrálního prstence.

\section{Výskyt, prognóza, vyšetření}

\subsection{Epidemiologie fibrilace síní}

Fibrilace síní bývá právem označována jako kardiovaskulární epidemie. Touto nejčastější poruchou srdečního rytmu je postiženo cca šest milionů Evropanů, odhadovaná prevalence $\mathrm{v}$ celkové populaci činí $1-2 \% .^{2}$ Mnoho dalších jedinců $\mathrm{v}$ populaci má formu asymptomatickou, nediagnostikovanou. $V$ prrišstích 50 letech se zřejmě prevalence FS až zdvojnásobí, nebot vzrůstá s věkem - ve věku do $40-50$ let $<0,5 \%$, ale ve věku nad 80 let dosahuje 
5-15\%. ${ }^{22}$ Evropské populační studie udávají prevalenci $5,5 \%$ u jedinců nad 55 let, incidenci 9,9/1 000 osobo-roků..$^{23}$ Častěji postihuje muže. Riziko onemocnění FS pro jedince staršího 40 let je cca $25 \%$. $^{24}$ To je pro srovnání více než např. pravděpodobnost onemocnění karcinomem prsu u žen (cca $11 \%)$.

\subsection{Prognóza}

Pacienti s fibrilací síní mají zvýšenou morbiditu i mortalitu oproti pacientům se sinusovým rytmem. Mortalita pacientů s FS je dvojnásobná, nezávisle na ostatních faktorech. ${ }^{25}$

Základní přičinou zvýšené morbidity při fibrilaci síní jsou tromboembolické př́hody. Riziko CMP je zvýšeno přibližně pětkrát, $\mathrm{v}$ závislosti na faktorech rizikové stratifikace tromboembolismu. Přibližně každá pátá CMP je podmíněna fibrilací síní, ${ }^{26}$ bývá navíc závažnější než CMP jiného původu. CMP spojené s fibrilací síní mají vyšší 30denní mortalitu, horší průběh, častější recidivy a dvakrát častěji jsou fatální. Rezidua po CMP při fibrilaci síní jsou výrazně horší než po CMP jiného původu. Pacienti s paroxysmální formou fibrilace síní mají podobné riziko CMP jako pacienti s formou perzistentní či permanentní. ${ }^{27}$ Riziko periferní embolizace mimo CNS je u mužů s fibrilací síní vyšší 4krát, u žen až 5,7krát. ${ }^{28}$

Fibrilace síní může být spojena se zhoršením kognitivních funkcí včetně vaskulární demence, zřejmě na podkladě asymptomatických cerebrálních mikroinfarktů. ${ }^{29}$ Zhoršuje kvalitu života, snižuje toleranci námahy, což bylo objektivizováno v několika studiích standardizovanými dotazníky. ${ }^{30}$ Hospitalizace při fibrilaci síní tvoří až třetinu všech hospitalizací pro arytmie. Hlavními důvody jsou akutní symptomy vyžadující léčbu, dále tromboembolické př́íhody, srdeční selhání a další. Srdeční selhání a fibrilace síní jsou provázaná onemocnění. Výskyt fibrilace síní při srdečním selhání je častější, v závislosti na jeho stupni o 10-25\%. Samotná fibrilace síní však může srdeční selhání zhoršovat nebo vyvolávat. U části pacientů se projevy srdečního selhání a dysfunkce levé komory vyskytují jen v důsledku fibrilace síní.

\subsection{Klinický obraz}

Fibrilace síní může být symptomatická i asymptomatická. Obtíže kolísají i u téhož pacienta, asymptomatických atak může být až 70 \%. Symptomy závisejí na frekvenci a pravidelnosti akce komor, trvání arytmie, přítomnosti srdečního onemocnění a individuální vnímavosti pacienta. Obvyklé jsou palpitace, bolest na hrudi, snížená tolerance zátěže, dušnost, únava, závratě. Prvním projevem může být i cévní mozková př́hoda nebo zhoršení srdečního selhání. Hemodynamické důsledky fibrilace síní souvisejí se třemi faktory: nepřiměřenou frekvencí komor, která je dána převodními vlastnostmi AV uzlu, nepravidelností akce komor a také ztrátou synchronizované akce síní. Pacienti s pomalejší a vyrovnanější akcí komor mají obtíže menší. Symptomatická bývá spíše paroxysmální FS, a to hlavně ve svých počátcích. U starších pacientů mohou být zhoršeny kognitivní funkce, a to jednak v důsledku hypoperfuze mozku, jednak v důsledku opakovaných mozkových embolizací. Nerozpoznané mikroembolizace jsou u některých nemocných s fibrilací síní patrně př́ičinou předčasné demence. K posouzení symptomů u fibrilace síní je navrhováno tzv. skóre EHRA $I-I V^{2}$ podobné klasifikaci symptomů při srdečním selhání NYHA I-IV. V praxi je jednodušší stupeň obtiží popsat jen slovně. Lze např. uvést, zda je fibrilace síní asymptomatická, symptomatická mírně nebo výrazně, prrípadně typ symptomů popsat.

Pacienti s fibrilací síní mají sníženou kvalitu života, především v závislosti na projevech arytmie. Kvalitu života však výrazně ovlivňuje i léčba. Např. nutnost častých kontrol je důvodem nízké adherence $\mathrm{k}$ dlouhodobé antikoagulační léčbě. Přispívá $\mathrm{k}$ tomu i výskyt krvácivých komplikací či jejich riziko, které by nemocný měl vzít v úvahu při výkonu některých povolání či sportovních aktivit s rizikem úrazu.

\subsection{Vyšetření pacientů s fibrilací síní}

Vstupní vyšetření pacientů s fibrilací síní nebo se suspektní fibrilací síní by mělo být zaměřeno na symptomy arytmie, př́datná onemocnění a event. komplikace fibrilace a rizikové faktory tromboembolie. Na základě těchto vyšetření by měla být pro daného pacienta stanovena klasifikace arytmie a strategie další léčby.

\subsubsection{Vstupní vyšetření u všech pacientů}

> Anamnéza: přítomnost fibrilace síní v rodině, základní symptomy (palpitace, dušnost, únavnost, snížená tolerance námahy, závratě, oprese na hrudi, synkopa), event. spouštěcí faktory arytmie (zátěž, emoce, alkohol), přídatná onemocnění (hypertenze, diabetes mellitus, srdeční selhání, ICHS, cévní mozkové příhody, onemocnění periferních tepen, tyreopatie, chronické plicní onemocnění), předchozí a stávající farmakoterapie, abúzus alkoholu;

> Fyzikální vyšetření včetně zjištění hodnoty krevního tlaku, hmotnosti a výšky;

>12svodové EKG: základní rytmus, ischemické změny, hypertrofie levé komory, raménkové blokády, preexcitace, převodní intervaly (PR, QRS, QT);

> Transthorakální echokardiografie: funkce levé komory, velikost síní, tlouštka stěn, chlopenní vady;

> Laboratorní vyšetření: hormony štítné žlázy, základní biochemie včetně iontů, koncentrace kreatininu, glykémie, lipidové spektrum, krevní obraz, základní koagulogram.

\subsubsection{Vyšetření indikovaná u vybraných pacientů}

> Zátěžový test (ergometrie, běhátko): při podezření na ICHS, ke kontrole odpovědi komor při zátěži;

> Ambulantní EKG monitorace:

> $\mathrm{u}$ jedinců s podezřením na fibrilaci síní: $\mathrm{k}$ záchytu fibrilace, korelace se symptomy, u pacientů s opakovanými synkopami, po cévní mozkové příhodě (včetně „kryptogenni“");

> u jedinců $s$ již zjištěnou fibrilací síní: $\mathrm{k}$ záchytu fibrilace včetně asymptomatických epizod, kontrola 
účinku léčby, kontrola odpovědi komor při FS. Možnosti EKG monitorace: kontinuální (holterovské) monitorování EKG (24 hodin až 7 dnů), transtelefonní epizodické záznamníky, externí smyčkové záznamníky (až několik týdnů), detekce síňových signálů z implantovaných kardiostimulátorů, defibrilátorů, implantabilní smyčkové záznamníky;

> Transezofageální echokardiografie: k vyloučení intrakardiální trombózy před elektrickou kardioverzí či katetrovou ablací, upřesnění nálezu z transthorakální echokardiografie.

\subsubsection{Vyšetření většinou neindikovaná u pacientů s fibrilací síní}

> Koronarografie: indikována dle platných doporučení pouze při symptomech či průkazu myokardiální ischemie, suspektní ICHS;

> Elektrofyziologické vyšetření: indikováno pouze při záchytu jiných supraventrikulárních arytmií, které mohou fibrilace síní spouštět a mohou být vyřešeny katetrovou ablací nebo jako součást vlastní katetrové ablace fibrilace síní.

\subsubsection{Sledování pacientů s fibrilací síní}

Vstupní vyšetření, klasifikaci a rozvahu o strategii léčby by měl zajistit kardiolog. Další sledování by mělo probíhat ve spolupráci kardiologa, internisty a praktického lékaře. Záleží na typu fibrilace, onemocnění srdce a dalších chorobách.

Kontrolní 12svodové EKG by mělo být sledováno $\mathrm{v}$ pravidelných intervalech, k ozřejmení aktuálního rytmu, vyloučení proarytmogenního vlivu antiarytmik atd. Při zhoršení stavu, změně charakteru onemocnění by měla být provedena kontrolní vyšetření, včetně např. EKG monitorace, echokardiografie atd.

Změny zdravotního stavu podmiňují nutnost opakované klasifikace stavu a rizik (tromboembolie, krvácivých komplikací, lékových interakcí, nežádoucích účinků léčiv apod.). Pacienti, u nichž je stávající terapie neúčinná, nebo je u nich zvažováno invazivní řešení fibrilace síní, by měli být odesláni do specializovaných kardiocenter.

\subsubsection{Náklady na péči}

Náklady na péči o pacienty s fibrilací síní jsou vysoké. Největší část $\mathrm{z}$ nich je spojena s hospitalizacemi (pro srdeční selhání, CMP, při provádění kardioverzí atd.) a dále s intervencí pro fibrilaci síní. Farmakoterapie se na všech vynaložených nákladech podílí asi $10 \%$, a to v zahraničí i v ČR. ${ }^{31}$ Podobnou finanční zátěž vyžaduje ambulantní sledování.

\section{Farmakoterapie pro fibrilaci síní}

Léčba fibrilace síní je zaměřena na léčbu a prevenci onemocnění, která $\mathrm{k}$ fibrilaci vedou, na prevenci tromboembolických př́hod a vlastní léčbu fibrilace. Tou rozumíme dva směry: obnovení a udržení sinusového rytmu - kontrolu srdečního rytmu, a optimalizaci srdeční frekvence - kontrolu frekvence. Rozhodnutí o konkrétním způsobu počáteční léčby vyžaduje zohlednění specifik individuálního nemocného, měla by tedy být „šitá na míru“ („patient-tailored therapy“). Zvolený postup pak musí být opakovaně aktualizován s ohledem na změny stavu pacienta a jeho reakce na dosavadní léčbu.

Pacient musí být detailně a opakovaně informován o individuálních možnostech terapie, její účinnosti a možných nežádoucích účincích, a to při použití všech způsobů léčby včetně antitrombotik, antiarytmik i postupů invazivních.

\subsection{Antitrombotická léčba}

$\mathrm{Na}$ základě mnoha studií byla $\mathrm{v}$ posledních pěti letech zjištěna větší nehomogennost rizikových faktorů pro vznik cévní mozkové příhody či tromboembolismu, než se předpokládalo. Ukázalo se, že existují možnosti přesnější predikce jejich rizika než dosud užívané skóre $\mathrm{CHADS}_{2}$ (tabulka 3). Současně jsou objevována nová účinná antitrombotika při sníženém riziku krvácení. To vše vedlo $\mathrm{k}$ potřebě obnovy doporučení pro antitrombotickou léčbu nemocných s fibrilací síní.

\subsubsection{Riziko tromboembolických komplikací}

\subsubsection{Riziková stratifikace}

Všechna schémata rizikové stratifikace cévní mozkové př́hody nebo tromboembolismu rozdělují nemocné do tři rizikových skupin - nízce riziková, středně riziková a vysoce riziková. Dle míry rizika se doporučovala warfarinizace pro vysoce rizikovou skupinu a kyselina acetylsalicylová pro nízce rizikovou skupinu. ${ }^{32}$

Nejjednodušším schématem pro hodnocení rizik je skóre $\mathrm{CHADS}_{2}$ (viz tabulku 3). CHADS 2 je zkratka vytvořená z prvních písmen názvů rizikových faktorů (srdeční selhání - cardiac failure, hypertenze, věk - age, diabetes mellitus, prodělaná cévní mozková prŕhoda - stroke ([dvojnásobná váha]). Skóre je index rizika vyvinutý na základě kritérií zjištěných při výzkumu fibrilace síní a prevence cévní mozkové př́hody. Je založen na bodovém systému, v němž se za cévní mozkovou př́hodu nebo transitorní ischemickou ataku v anamnéze prridělují dva body a po jednom bodu pak za každý z ostatních rizikových faktorů: věk vyšší než 75 let, vysoký krevní tlak v anamnéze, diabetes mellitus nebo nedávné srdeční selhání. ${ }^{33,34}$

Řada studií sledovala nové rizikové faktory. Cílem je zvýšení prediktivní hodnoty rizikové stratifikace CMP či

Tab. 3 Kritéria rizikové stratifikace tromboembolie $\mathrm{CHADS}_{2}$

\begin{tabular}{ll}
\hline Riziková kritéria CHADS $_{2}$ & Skóre \\
\hline Prodělaná CMP nebo TIA & 2 \\
\hline Věk $\geq 75$ let & 1 \\
\hline Hypertenze & 1 \\
\hline Diabetes mellitus & 1 \\
\hline Srdeční selhání & 1 \\
\hline CMP - cévní mozková př́hoda, TIA - transitorní ischemická ataka
\end{tabular}


tromboembolismu. Kromě dosavadních rizikových faktorů se zjistilo, že riziko představuje věk již od 65 let, význam má také přítomnost aterosklerotického cévního postižení a ženské pohlaví.

\subsubsection{Nové možnosti rizikové stratifikace}

Modifikace prrístupu hodnocení rizikových faktorů tromboembolie u pacientů s nevalvulární fibrilací síní lze vyjádřit zkratkou $\mathrm{CHA}_{2} \mathrm{DS}_{2}-\mathrm{VASc}$ (městnavé selhání srdce - chronic heart failure, hypertenze, věk $\geq 75$ let - age [dvojnásobná váha], diabetes mellitus, mozková př́hoda $\mathrm{v}$ anamnéze stroke [dvojnásobná váha], cévní choroba - vascular disease, věk 65-74 let - age a ženské pohlaví - sex category). ${ }^{35}$ Toto schéma je založeno na bodovacím systému, v němž se dva body přidělují za CMP či transitorní ischemickou ataku $\mathrm{v}$ anamnéze a za věk nad 75 let. Po jednom bodu se pak přiděluje za věk v rozmezí 65-74 let a předchozí výskyt hypertenze, diabetu, nedávného srdečního selhání, cévní choroby (infarktu myokardu, komplikovaného plátu v aortě a onemocnění periferních tepen, včetně předchozí revaskularizace, amputace zaviněné onemocněním periferních tepen či angiograficky prokázaného onemocnění apod.) a ženské pohlaví (tabulka 4). Schéma charakterizované zkratkou $\mathrm{CHA}_{2} \mathrm{DS}_{2}$-VASc tedy rozšiřuje skóre $\mathrm{CHADS}_{2}$.

Za rizikový faktor se pokládá neléčená hypertenze > 160/95 mm Hg nebo hypertenze korigovaná léčbou. Přítomnost závažnější systolické dysfunkce levé komory při echokardiografickém vyšetření (ejekční frakce levé komory [EFLK] $\leq 40 \%$ ) se ukázala jako jasný nezávislý rizikový faktor CMP. Riziko tromboembolismu u srdečního selhání při zachované systolické funkci levé komory není zatím přesně definováno.

Také přítomnost aterosklerotického cévního onemocnění představuje zvýšené riziko CMP. Závažnost jednotlivých cévních onemocnění však není stejná. Prodělaný infarkt myokardu zvyšuje riziko $\mathrm{CMP} /$ tromboembolismu, ${ }^{36}$ ale diagnóza samotné anginy pectoris je nespolehlivá, jelikož část těchto nemocných nemusí mít sklerotické postižení koronárních tepen. Fibrilace síní značí špatnou prognózu také

\begin{tabular}{|c|c|}
\hline Rizikové faktory dle $\mathrm{CHA}_{2} \mathrm{DS}_{2}$-VASc stratifikace & Body - skóre \\
\hline Prodělaná CMP nebo TIA & 2 \\
\hline Věk $\geq 75$ let & 2 \\
\hline Hypertenze & 1 \\
\hline Diabetes mellitus & 1 \\
\hline Srdeční selhání/levokomorová dysfunkce & 1 \\
\hline Věk 65-74 let & 1 \\
\hline Ženské pohlaví & 1 \\
\hline $\begin{array}{l}\text { Cévní onemocnění (prodělaný infarkt myokardu, periferní } \\
\text { arteriální onemocnění, aortální sklerotický plát) }\end{array}$ & 1 \\
\hline Maximum & 9 \\
\hline
\end{tabular}

u pacientů s onemocněním periferních tepen. Nezávislým rizikovým faktorem pro cévní mozkovou prríhodu a tromboembolii je př́tomnost komplikovaného plátu v sestupné části aorty zjištěná jícnovou echokardiografií. Analýza četných studií a registrů nově stanovila, že ženy mají vyšší riziko tromboembolismu, jako je tomu u rizikových faktorů věku a hypertenze. Při jícnovém echokardiografickém vyšetření jsou nezávislými indikátory hrozící cévní mozkové př́hody a tromboembolie sraženina v levé síni (relativní riziko [RR] 2,5), komplikované pláty $\mathrm{v}$ aortě ( $\mathrm{RR} 2,1$ ), spontánní echokontrast (RR 3,7) a nízké rychlosti průtoku v oušku levé srdeční síně $(<20 \mathrm{~cm} / \mathrm{s})$. Jsou-li prrítomny rizikové faktory u pacientů s paroxysmální fibrilací síní, mělo by u nich být riziko cévní mozkové př́ihody stejné jako při formě perzistující.

Při sledování dalších onemocnění u nemocných s fibrilací síní byly zjištěny i další faktory, které představují zvýšené riziko tromboembolismu. Je to např. chronické onemocnění ledvin. Nedávná analýza naznačuje, že proteinurie zvyšuje riziko tromboembolie o $54 \%$, přičemž zvýšené riziko cévní mozkové př́hody nastává u odhadované úrovně glomerulární filtrace $<45 \mathrm{ml} / \mathrm{min}$. Dalšími riziky mohou být hypertyreóza, hypertrofická kardiomyopatie, amyloidóza a řada dalších. Tyto faktory však současně zvyšují mortalitu a krvácivé komplikace a nebyly prospektivně sledovány, proto jejich závažnost ve vztahu $\mathrm{k}$ tromboembolii není stanovena.

\subsubsection{Doporučení k antitrombotické léčbě podle rizikové stratifikace}

Evropská doporučení navrhují, aby se lékaři při stratifikací rizika cévní mozkové příhody/tromboembolie nadále zpočátku řídili dle skóre $\mathrm{CHADS}_{2}$. Tento návrh odůvodňují jednoduchostí a dobrou zapamatovatelností již vžitého skórovacího systému. Nová stratifikace rizika skóre $\mathrm{CHA}_{2} \mathrm{DS}_{2}$-VASc není proti původní stratifikaci rizika dle $\mathrm{CHADS}_{2}$ výrazněji složitější, ale má podstatně větší prediktivní hodnotu pro stanovení rizika cévní mozkové př́hody nebo tromboembolie.

Nové schéma velmi dobře identifikuje nemocné $\mathrm{s}$ fibrilací síní, kteří jsou skutečně $\mathrm{v}$ nízkém riziku $\left(\mathrm{CHA}_{2} \mathrm{DS}_{2}-\mathrm{VASc}=0\right)^{35}$, u nichž není nutná žádná prevence tromboembolie. Nové skóre také dobře vymezuje skupinu nemocných se středním rizikem tromboembolizace $\left(\mathrm{CHA}_{2} \mathrm{DS}_{2}\right.$-VASc $\left.=1\right)-\mathrm{v}$ tom prípadě lze volit mezi léčbou antikoagulační a antiagregační, přičemž preferenční je léčba antikoagulační. Pacientů v tomto středním riziku s možností volby léčby je podle skóre $\mathrm{CHA}_{2} \mathrm{DS}_{2}$-VASc $15 \%$, tedy daleko méně než dřivějších $62 \%$ podle skóre $\mathrm{CHADS}_{2}$. U ostatních pacientů se skóre $\mathrm{CHA}_{2} \mathrm{DS}_{2}-\mathrm{VASc} \geq 2$ je doporučena léčba antikoagulační (tabulka 5).

U skupiny nemocných se skóre $\mathrm{CHADS}_{2}=0$ byl roční výskyt CMP či embolizace $1,4 \%$. Při nové stratifikací nedošlo u nemocných ve skutečně nízkém riziku (skóre $\mathrm{CHA}_{2} \mathrm{DS}_{2}$-VASc $\left.=0\right) \mathrm{k}$ žádné tromboembolické př́ihodě, proto se těmto nemocným nemusí podávat žádná antitrombotická léčba. Doposud se u nemocných v nízkém riziku (skóre $\mathrm{CHADS}_{2}=0$ ) doporučovalo podání kyseliny 
Tab. 5 Doporučení pro prevenci tromboembolismu dle rizikových faktorů stratifikace $\mathrm{CHA}_{2} \mathrm{DS}_{2}$-VASC

\begin{tabular}{ll}
\hline Rizikové faktory dle tabulky 4 & Doporučená antitrombotická léčba \\
\hline Skóre $=0$ & Kyselina acetylsalicylová \\
Minimální riziko CMP/TE & $75-325 \mathrm{mg} /$ den, nebo žádná \\
& antitrombotická léčba \\
& Preference: žádná antitrombotická \\
& léčba \\
\hline Skóre $=1$ & Kyselina acetylsalicylová \\
Strední riziko CMP/TE & $75-325 \mathrm{mg} /$ den nebo warfarin \\
& (INR $=2,0-3,0-$ optimální \\
& INR $=2,5)$, případně dabigatran \\
& $2 \times 150(2 \times 110) \mathrm{mg} /$ den* \\
& Preference: warfarin (případně nová \\
& antitrombotika**) \\
\hline Skóre $>1$ & Warfarin (INR $=2,0-3,0$ - optimální \\
Vysoké riziko CMP/TE & INR $=2,5)$, případně dabigatran \\
& $2 \times 150(2 \times 110) \mathrm{mg} /$ den* \\
& Preference: warfarin (případně nová \\
& antitrombotika**)
\end{tabular}

INR - mezinárodní normalizovaný poměr, CMP - cévní mozková příhoda TE - tromboembolismus, * Podrobně dle SPC; ${ }^{* *}$ viz kapitola 4.3.2.1.

acetylsalicylové, což vedlo k určitému množství krvácivých komplikací. Navíc kyselinu acetylsalicylovou dostávala také velká část nemocných v riziku středním (skóre $\mathrm{CHADS}_{2}=1$ ), což při podhodnocení rizika vedlo $\mathrm{k}$ trombembolickým komplikacím.

Podle $\mathrm{CHA}_{2} \mathrm{DS}_{2}$-VASc stratifikace tromboembolismu má více než $90 \%$ pacientů s fibrilací síní skóre $\geq 1$. Lze tedy shrnout, že v současné době je antikoagulační léčba vhodná pro naprostou většinu pacientů s fibrilací síní, s výjimkou mužů mladších než 65 let věku a bez dalších rizikových faktorů. Také u žen mladších 65 let, u nichž se nevyskytují žádné další rizikové faktory, lze uvažovat spíše o použití kyseliny acetylsalicylové než o léčbě perorálními antikoagulancii.

\subsubsection{Riziko krvácivých komplikaci}

Př́nos antikoagulační léčby v prevenci CMP mnohonásobně převažuje nad rizikem intrakraniálního krvácení. Přesto je potřeba od počátku rizika krvácení zhodnotit. Antikoagulační léčba se dnes používá u starších pacientů s fibrilací síní, avšak procentuální výskyt nitrolebního krvácení je podstatně nižší než v minulosti a typicky se v současných výsledkových zprávách pohybuje v rozmezí 0,1-0,6\%. Př́činou může být nižší intenzita antikoagulační léčby, pečlivější úprava dávkování nebo lepší kontrola vysokého krevního tlaku. Výskyt nitrolebního krvácení stoupá až s hodnotami INR převyšujícími 3,5-4,0, hodnoty v rozmezí 2,0-3,0 nevykazují ve srovnání s nižšími hodnotami INR žádný nárůst rizika krvácení.

Lze předpokládat, že riziko závažného krvácení při podávání kyseliny acetylsalicylové je obdobné jako u antagonistů vitaminu K, zejména u starších osob. ${ }^{37}$ Strach z pádů je patrně přeceňován, protože $\mathrm{k}$ tomu, aby riziko nitrolebního krvácení převážilo nad přínosem antikoagulační léčby, by musel pacient spadnout zhruba 300krát za rok.

$\mathrm{Na}$ základě zkušeností z praxe (studie EuroHeart čítající 3978 nemocných s fibrilací síní) bylo vyvinuto nové jednoduché skóre pro hodnocení rizika krvácení - skóre $H A S-B L E D$. Název je odvozen opět od počátečních písmen rizikových faktorů krvácení (hypertenze, abnormální funkce ledvin/jater, mozková př́ihoda (stroke), krvácení (bleeding) $\mathrm{v}$ anamnéze nebo predispozice $\mathrm{k}$ němu, labilní INR, vyšší věk (elderly), tj. věk nad 65 let, užívání léčiv zvyšujících krvácení (drugs) a/nebo alkoholu současně s antikoagulační léčbou (tabulka 6).

Skóre $\geq 3$ poukazuje na vysoké riziko. V takovýchto případech je tedy třeba po zahájení antitrombotické léčby, at' už antagonisty vitaminu $\mathrm{K}$ či kyselinou acetylsalicylovou, zvýšená opatrnost a pravidelná kontrola pacientova stavu. Neznamená to tedy, že antitrombotickou léčbu nemáme podávat. Perspektivně lze při vysokém riziku krvácení zvážit nová antitrombotika.

\subsubsection{Optimální antikoagulační léčba}

\subsubsection{Antikoagulační léčba antagonisty vitaminu K vs. kontrolni skupina}

V letech 1989-1992 byly uveřejněny výsledky pěti velkých randomizovaných studií, které hodnotily účinnost antagonistů vitaminu $\mathrm{K}$ zejména $\mathrm{v}$ primární prevenci tromboembolie u pacientů s nevalvulární fibrilací síní. Šestá studie byla zaměřena na sekundární prevenci u pacientů, kteří přežili neinvalidizující CMP či transitorní ischemickou ataku. Při metaanalýze bylo snížení relativního rizika užíváním antagonistů vitaminu $\mathrm{K}$ velmi významné, na úrovni $64 \%$, což odpovídá absolutnímu ročnímu snížení rizika všech typů cévních mozkových príhod o 2,7 \%. ${ }^{9}$ Pokud byly brány $\mathrm{v}$ úvahu pouze ischemické mozkové příhody,

\section{Tab. 6 Stanovení rizika krvácení dle rizikové stratifikace HAS-BLED}

\begin{tabular}{lll}
\hline $\begin{array}{l}\text { První písmeno } \\
\text { rizikového faktoru }\end{array}$ & Rizikový faktor krvácení & $\begin{array}{l}\text { Body - } \\
\text { skóre }\end{array}$ \\
\hline H - hypertension & Hypertenze & 1 \\
\hline A - abnormal & $\begin{array}{l}\text { Porucha ledvinných či jaterních } \\
\text { funkcí (1 bod za každou) }\end{array}$ & 1 nebo 2 \\
\hline S - stroke & Cévní mozková př́hoda & 1 \\
\hline B - bleeding & Krvácení & 1 \\
\hline L- labile & Kolísavá hodnota INR & 1 \\
\hline E- elderly & Věk > 65 let & 1 \\
\hline D - drugs & Léky nebo alkohol (1 bod za každý) & 1 nebo 2 \\
\hline Maximum & & 9
\end{tabular}

INR - mezinárodní normalizovaný poměr. Hypertenze je definována jako systolický tlak krve > 160 mm Hg. Abnormální funkce ledvin je definována jako prítomnost chronické dialýzy nebo stav po transplantaci ledviny nebo koncentrace kreatininu $v$ séru $\geq 200 \mu \mathrm{mol} / \mathrm{l}$. Abnormální funkce jater jsou definovány jako chronické onemocnění jater (např. cirhóza) nebo biochemické poškození jater ve smyslu signifikantně zvýšené sérové koncentrace bilirubinu (dvojnásobek horního limitu normy ve spojení s trojnásobkem horního limitu normy u aminotransferáz - AST/ALT/alkalická fosfatáza). Krvácení znamená krvácení v anamnéze nebo přítomnost predispozice ke krvácení (krvácivá diatéza, anemie aj.). Jako kolísavá hodnota INR jsou nestabilní/vysoké hodnoty INR nebo časté hodnoty mimo terapeutické rozmezí (např. $60 \%$ ). Léky nebo alkoholem je míněna doprovodná léčba např. antiagregancii, nesteroidními antiflogistiky nebo nadměrná konzumace alkoholu. 
užívání antagonistů vitaminu $\mathrm{K}$ v kontrolovaném režimu vedlo k 67\% snížení relativního rizika. Toto snížení bylo podobné u primární i sekundární prevence a u invalidizujících i neinvalidizujících mozkových příhod. Mnoho případů CMP, které se vyskytly u pacientů užívajících antagonisty vitaminu $\mathrm{K}$, se přihodilo $\mathrm{v}$ době, kdy se nemocní neléčili nebo dostávali subterapeutické dávky antikoagulancií. Úmrtnost ze všech příčin se užíváním adjustovaných dávek antagonistů vitaminu K oproti kontrolní skupině významně snížila (o 26 \%). Riziko mozkového krvácení bylo malé.

\subsubsection{Protidestičková léčba}

Ovlivnění rizika tromboembolie u nemocných s fibrilací síní podáváním protidestičkové léčby (převážně kyseliny acetylsalicylové) bylo ověřováno v osmi nezávislých randomizovaných kontrolovaných studiích, jichž se dohromady účastnilo 4876 pacientů. ${ }^{9} \mathrm{~V}$ sedmi z nich, kdy bylo porovnáváno pouze užívání kyseliny acetylsalicylové a placeba, vykazovala léčba kyselinou acetylsalicylovou nevýznamné snížení výskytu cévních mozkových př́hod. Snížení absolutního rizika $\mathrm{v}$ tomto př́padě bylo na úrovni $0,8 \%$ za rok u studií primární prevence a 2,5 \% za rok u studií prevence sekundární. Kyselina acetylsalicylová byla také spojována s 13\% snížením výskytu invalidizujících mozkových př́hod a s $29 \%$ redukcí výskytu mozkových příhod neinvalidizujících. Pokud byly uvažovány pouze ischemické mozkové příhody, vedlo užívání kyseliny acetylsalicylové k $21 \%$ snížení jejich výskytu. Teze o př́znivých účincích kyseliny acetylsalicylové se Z velké části opírá o výsledky jediné pozitivní studie SPAF-I, z níž vyplynulo 42\% snížení rizika CMP při užívání 325 mg kyseliny acetylsalicylové ve srovnání s placebem. Význam této studie je patrně nadhodnocován. Míra snížení rizika cévní mozkové příhody léčbou kyselinou acetylsalicylovou oproti použití placeba je při metaanalýze přibližně stejná jako $\mathrm{v}$ př́padech, kdy je kyselina acetylsalicylová podávána pacientům s cévním onemocněním.

Podávané dávky kyseliny acetylsalicylové se u jednotlivých studií podstatně lišily, pohybovaly se od $50 \mathrm{mg}$ po $1300 \mathrm{mg}$ za den. Z farmakologického hlediska se dosáhne téměř úplné inhibice destiček již př̀i dávce $75 \mathrm{mg}$. Nízké dávky (<100 mg) jsou navíc bezpečnější než vyšší (> 300 mg), při nichž stoupá výskyt krvácení. Pokud je tedy pacient léčen kyselinou acetylsalicylovou, je rozumné používat dávky pohybující se u dolní hranice povoleného dávkování (75-100 mg denně).

Vzhledem k mírnému či spornému účinku kyseliny acetylsalicylové na výskyt CMP provázené určitým rizikem krvácivých komplikací podobným riziku při léčbě antagonisty vitaminu $\mathrm{K}$ se dnes pacientům s nízkým rizikem tromboembolie spíše než užívání kyseliny acetylsalicylové doporučuje nepodávat léčbu žádnou. Postup je však jistě individuální.

\subsubsection{Antikoagulační léčba antagonisty vitaminu K vs. protidestičková léčba}

Př́mé srovnání účinků antagonistů vitaminu $\mathrm{K}$ a kyseliny acetylsalicylové bylo provedeno $\mathrm{v}$ devíti studiích a bylo pro- kázáno, že antagonisté vitaminu K jsou podstatně účinnější a snižují relativní riziko o 39 \%. Studie BAFTA u pacientů s fibrilací síní starších 75 let ukázala, že antagonisté vitaminu K (cílová hodnota INR 2-3) byly při snižování rizika primárního výsledného ukazatele, tj. fatální nebo invalidizující cévní mozkové příhody (ischemické nebo hemoragické), nitrolebního krvácení nebo klinicky významné tepenné embolie, o 52 \% účinnější než podávání kyseliny acetylsalicylové v dávce 75 mg denně. Rizikem závažného krvácení se užívání kyseliny acetylsalicylové nelišilo od podávání warfarinu. ${ }^{10}$ Podle studií provedených dříve bylo riziko nitrolebního krvácení při užívání warfarinu dvojnásobné oproti riziku spojenému s podáváním kyseliny acetylsalicylové, byt nárůst absolutního rizika byl malý ( $0,2 \%$ ročně).

\subsubsection{Kombinovaná antitrombotická léčba}

Antikoagulační léčba je účinnější než duální antiagregační léčba (kyselina acetylsalicylová + clopidogrel). Ukázala to studie ACTIVE W. U nemocných se středním a vyšším rizikem (skóre $\mathrm{CHADS}_{2} \geq 1$ ) má oproti duální antiagregaci statisticky významně větší prrínos antikoagulační léčba, ${ }^{38}$ výskyt krvácivých komplikací při této duální antiagregaci byl podobný.

Studie ACTIVE A ukázala, že duální antiagregační léčba je účinnější než uživání samotné kyseliny acetylsalicylové (relativní snížení CMP -28\%). Tato duální léčba oproti monoterapii kyselinou acetylsalicylovou ale také vede $\mathrm{k}$ signifikantnímu zvýšení velkých krvácivých komplikací (2 \% versus $1,3 \%) .{ }^{39} \mathrm{~V}$ evropských i amerických doporučeních se u pacientů, kteří z nějakých důvodů nemohou užívat warfarin a nemají vysoké riziko krvácivých komplikací, uvádí možnost kombinaci kyseliny acetylsalicylové a clopidogrelu podávat. $\mathrm{V}$ současné době, kdy začínají být $\mathrm{k}$ dispozici přímé inhibitory trombinu nebo inhibitory faktoru Xa, uvedenou duální antiagregaci nelze doporučit ani u této skupiny nemocných.

Kombinace antikoagulační léčby s léčbou antiagregační nepřináší snížení výskytu tromboembolií, ale naopak zvyšuje výskyt krvácivých komplikací. Proto v případě, když $\mathrm{k}$ tromboembolii dojde při účinné antikoagulační léčbě (INR 2,0-3,0), nedoporučuje se přidat antiagregační léčbu, nýbrž zvýšit účinnost antikoagulace (INR 3,0-3,5), jelikož riziko závažného krvácení se zvyšuje až při hodnotě INR > 3,5.

\subsubsection{Alternativy antikoagulační léčby}

\subsubsection{Nová antitrombotika}

V současné době se vyvíjí nebo již postupně přichází na trh několik nových antikoagulačních léků, které spadají převážně do dvou kategorií:

1. perorální př́mé inhibitory trombinu, tzv. "gatrany“ (např. dabigatran etexilát),

2. perorální inhibitory faktoru Xa, tzv. „Xabany“ (rivaroxaban, apixaban, edoxaban, betrixaban, YM150 atd.).

Doposud byly publikovány tři srovnávací studie nových perorálních antitrombotik a warfarinu u pacientů s fibrilací síní (tabulka 7). 
Tab. 7 Základní srovnávací charakteristiky průkazných studií s novými perorálními antitrombotiky

\begin{tabular}{|c|c|c|c|}
\hline $\begin{array}{l}\text { Charakteristika } \\
\text { studií }\end{array}$ & $\begin{array}{l}\text { RELY } \\
\text { dabigatran }\end{array}$ & $\begin{array}{l}\text { ARISTOTLE } \\
\text { apixaban }\end{array}$ & $\begin{array}{l}\text { ROCKET AF } \\
\text { rivaroxaban }\end{array}$ \\
\hline $\begin{array}{l}\text { Mechanismus } \\
\text { účinku }\end{array}$ & Faktor Ila & Faktor Xa & Faktor Xa \\
\hline Počet pacientů & 18113 & 18201 & 14264 \\
\hline Dávkování & $\begin{array}{l}150 \text { mg } 2 \times \text { denně } \\
110 \text { mg } 2 \times \text { denně }\end{array}$ & $\begin{array}{l}5 \text { mg } \\
2 \times \text { denně } \\
\text { ( } 2,5 \text { mg } \\
2 \times \text { denně })\end{array}$ & $\begin{array}{l}20 \text { mg } \\
1 \times \text { denně } \\
\text { (15 mg } \\
1 \times \text { denně) }\end{array}$ \\
\hline $\begin{array}{l}\text { Průměr skóre } \\
\mathrm{CHADS}_{2}\end{array}$ & 2,1 & 2,1 & 3,5 \\
\hline Průměr TTR & $64 \%$ & $62 \%$ & $55 \%$ \\
\hline Medián TTR & $67 \%$ & $66 \%$ & $58 \%$ \\
\hline $\begin{array}{l}\text { Přerušení } \\
\text { léčby - studijní } \\
\text { lék/warfarin }\end{array}$ & $21,2 \% / 16,6 \%$ & $25,3 \% / 27,5 \%$ & $\begin{array}{l}23,9 \% / \\
22,4 \%\end{array}$ \\
\hline
\end{tabular}

Randomizovaná studie RE-LY ${ }^{40}$ porovnávala dabigatran etexilát $\mathrm{s}$ warfarinem $\mathrm{v}$ prevenci tromboembolických př́hod u nemocných s fibrilací síní a nejméně jedním rizikovým faktorem pro vznik cévní mozkové př́hody. Studie se zúčastnilo přes 18000 nemocných a ukázala, že ve skupině léčené warfarinem se CMP nebo systémové embolizace vyskytly u $1,71 \%$ sledovaných/rok, zatímco ve skupině léčené dabigatranem $\mathrm{v}$ dávce $2 \times 110 \mathrm{mg}$ denně u $1,54 \%$ a ve skupině léčené dabigatranem v dávce $2 \times 150$ mg denně u 1,11 \% sledovaných/rok. Z výsledků vyplývá, že dabigatran $\mathrm{v}$ dávce $2 \times 110 \mathrm{mg}$ nebyl v prevenci cévní mozkové př́hody a systémové tromboembolie horší než warfarin $(\mathrm{p}<0,001)$ a dabigatran $\mathrm{v}$ dávce $2 \times 150 \mathrm{mg}$ byl účinnější než warfarin ( $\mathrm{p}<0,001)$. Výskyt krvácivých komplikací byl při dávce dabigatranu $2 \times 150 \mathrm{mg}$ srovnatelný, při dávce $2 \times 110 \mathrm{mg}$ nižší. Důležité je, že při použití obou dávek byl nižší výskyt závažných mozkových krvácení.

Studie ROCKET-AF ${ }^{41}$ byla dvojitě zaslepená randomizovaná studie, která porovnávala rivaroxaban v dávce $20 \mathrm{mg}$ $1 \times$ denně s warfarinem $\mathrm{v}$ prevenci cévní mozkové prŕhody a tromboembolických príhod u nemocných s fibrilací síní ve zvýšeném riziku vzniku CMP. U více než 14000 nemocných ukázala, že ve skupině léčené warfarinem byl výskyt cévní mozkové př́hody nebo systémových embolizací u 2,2\% sledovaných/rok, zatímco ve skupině léčené rivaroxabanem u 1,7 \% sledovaných/rok. Hodnocení výsledků závisí na způsobu analýzy. Rivaroxaban nebyl v prevenci cévní mozkové př́ihody a tromboembolizace horší než warfarin (analýza „intention-to treatment“), resp. naopak byl účinnější (analýza „on treatment“). Výskyt krvácivých komplikací byl 14,5\%/rok ve skupině léčené warfarinem a 14,9\% ve skupině léčené rivaroxabanem, tedy srovnatelný, výskyt závažných krvácivých komplikací (včetně krvácivých CMP) při podávání rivaroxabanu byl nižší. Naopak méně závažná krvácení a nutnost podávání transfuzí byla častější.
V srpnu 2011 byly prezentovány výsledky studie ARISTOTLE. ${ }^{42}$ Ta porovnávala apixaban $\mathrm{v}$ dávce $5 \mathrm{mg}$ $2 \times$ denně $s$ warfarinem $\mathrm{v}$ prevenci cévní mozkové příhody a systémových tromboembolických příhod u nemocných s fibrilací síní ve zvýšeném riziku vzniku CMP. Ve studii se u více než 18000 pacientů prokázalo, že při podávání warfarinu byl výskyt CMP nebo systémových embolizací u 1,6\%/rok, zatímco ve skupině léčené apixabanem u 1,27 \% sledovaných/rok. Z výsledků vyplývá, že apixaban byl účinnější než warfarin. V této studii také poprvé dosáhl významnosti rozdíl v ovlivnění celkové mortality, která byla při apixabanu nižší. Výskyt velkých krvácivých komplikací byl 3,09\%/rok ve skupině léčené warfarinem a 2,13\% ve skupině léčené apixabanem. Také výskyt závažných krvácivých komplikací byl nižší. Celkově tedy lze uzavřít, že v prevenci cévní mozkové př́hody a systémové embolizace byl apixaban $\mathrm{v}$ dávce $2 \times 5 \mathrm{mg}$ účinnější než warfarin a byl spojen s nižším výskytem krvácivých komplikací.

\subsubsection{Postavení nových antitrombotik v rámci doporučení}

$\mathrm{V}$ současnosti jsou $\mathrm{k}$ dispozici data, která již u tři nových antitrombotik prokazují srovnatelnou či vyšši účinnost oproti warfarinu u pacientì s fibrilací síní, a to s nižším nebo srovnatelným výskytem krvácivých komplikací. Evropská guidelines však ještě $\mathrm{k}$ antikolagulační léčbě u pacientů s fibrilací síní uvádějí pouze warfarin. Je tedy zřejmé, že bude třeba (v závislosti na průběhu schvalovacích procesů) vydávání dodatků $\mathrm{k}$ doporučením.

Evropská guidelines pouze předpokládají použití dabigatranu jako alternativu $\mathrm{k}$ warfarinu a navrhují i způsob dávkování. Evropská agentura pro léčiva (European Medicines Agency, EMA) vydala v srpnu 2011 doporučení pro užívání dabigatranu $\mathrm{v}$ prevenci cévní mozkové př́hody a tromboembolie u nemocných s fibrilací síní bez chlopenní vady. Doporučené dávky se zde od návrhu uvedeného v evropských guidelines liší. Doporučeno je dlouhodobé podávání dabigatranu v dávce $2 \times 150$ mg denně, nižší dávka $2 \times 110$ mg je nutná u osob ve věku $\geq 80$ let a u pacientů užívajících současně verapamil. Nižší dávku je třeba zvážit také u nemocných ve věku 75-80 let, kteří mají vysoké riziko krvácení, u nemocných se středně závažnou poruchou funkce ledvin (clearance kreatininu 30-50 $\mathrm{ml} / \mathrm{min}$ ) a u osob s gastritidou, ezofagitidou nebo gastroezofageálním refluxem. U nemocných s těžkou poruchou funkce ledvin (clearance kreatininu $<30 \mathrm{ml} / \mathrm{min}$ ) je dabigatran kontraindikován. Všichni nemocní se zvýšeným rizikem krvácivých komplikací by měli být důkladně sledováni a dávka dabigatranu by měla být snížena podle úvahy lékaře. V souladu s doporučeními Evropské agentury pro léčiva lze upřesnit podávání dabigatranu za dalších klinických situací (postup dle SPC).

Podávání dabigatranu může být rovněž zváženo u nemocných, kteří jsou indikováni $\mathrm{k}$ antikoagulační léčbě, ale není pro ně z jakéhokoli důvodu vhodné užívání warfarinu. Doposud se v takovém př́padě jako alternativní léčba uváděla možnost podávání duální antiagregace (kyselina acetylsalicylová + clopidogrel). 
Dabigatran jako prevence tromboembolie u pacientů s fibrilací síní byl schválen rovněž ve Spojených státech amerických, což vedlo k vydání dodatku ke guidelines. Proti evropským doporučením je v USA dávkování odlišné byla schválena pouze dávka $2 \times 150 \mathrm{mg}$, resp. u pacientů s renálním selháním dávka $2 \times 75 \mathrm{mg}$ (netestovaná ve studii RE-LY).

Dalši nová antitrombotika zatím (v době revize těchto doporučení) pro prevenci tromboembolismu $u$ pacientů s fibrilací síní nebyla schválena (v USA doporučil poradní výbor FDA v září 2011 schválení rivaroxabanu, pozitivní doporučující stanovisko je vydáno také pro Evropskou agenturu pro léčiva [EMA]). Nová antitrombotika mají oproti antagonistům vitaminu $\mathrm{K}$ z hlediska praktického užití řadu výhod. Dávkování je fixní, není třeba rutinního monitorování léčby, nevyskytují se závažné interakce s potravinami, mají nízký potenciál pro interakce s léky. Účinek rychle nastupuje i odeznívá. $\mathrm{Na}$ rozdíl od antagonistů vitaminu $\mathrm{K}$ však zatím není dostupné antidotum. Všechna antikoagulancia inhibují koagulaci blokováním tvorby trombinu, trombinové aktivity nebo blokací obojího.

Výsledky studií s dabigatranem, rivaroxabanem a apixabanem potvrzují antikoagulační funkci trombinu i faktoru Xa a zatím neexistuje žádný přesvědčivý důkaz, zda je lepší ovlivnění jednoho faktoru, či druhého. Bylo by třeba prrímého vzájemného porovnání nových antikoagulancií, v nejbližší budoucnosti jsou však takové srovnávací studie nepravděpodobné. Neprrimé srovnání nových antitrombotik napřić jednotlivými studiemi je problematické, jelikož může být zkresleno různou závažností onemocnèní jednotlivých sledovaných skupin nemocných, různými kombinacemi doprovodných onemocnèní, různými typy intervencí $i$ způsoby hodnocení účinku léčby. Z toho pramení rozpaky při porovnávání rozdílných výsledku jednotlivých studií.

\subsubsection{Současná doporučení pro antitrombotickou léčbu}

Schéma hodnocení rizika tromboembolie $\mathrm{CHADS}_{2}$ by mělo být používáno jako jednoduchý výchozí a snadno zapamatovatelný nástroj pro odhad rizika cévní mozkové př́hody, zejména pro praktické lékaře. Pokud se nevyskytnou kontraindikace, doporučuje se u pacientů se skóre $\mathrm{CHADS}_{2} \geq 2$ dlouhodobá léčba antagonisty vitaminu $\mathrm{K}$, při terapii warfarinem je doporučováno dosažení INR v rozmezí 2,0-3,0. U pacientů, kteří mají skóre $\mathrm{CHADS}_{2}$ v rozpětí $0-1$, se doporučuje použít komplexnější bodovací systém - skóre $\mathrm{CHA}_{2} \mathrm{DS}_{2}$-VASc.

Za účinnou a optimální antikoagulační léčbu v prevenci cévní mozkové př́hody a tromboembolie dnes lze pokládat jednoznačné udržení hodnot INR v rozmezí 2,0-3,0. Celkový počet hodnot $\mathrm{v}$ terapeutickém rozmezí by měl být co nejvyšší. Ze studií se ukázalo, že je velmi důležitá doba s hodnotami INR v terapeutickém rozmezí (time in therapeutic range, TTR). Ve studiích se pohybovala průměrně mezi 57-65\%. Čím nižší procento, tím nižší byl terapeutický účinek. Při poklesu pod $60 \%$ je preventivní účinek výrazně snížen.

U nemocných s umělou chlopenní náhradou by se hodnota INR měla držet minimálně na hodnotě INR $\geq 2,5$ $\mathrm{v}$ mitrální pozici a minimálně na hodnotě $\mathrm{INR} \geq 2,0$ $\mathrm{v}$ pozici aortální. $\mathrm{V}$ př́ípadě, že dojde $\mathrm{k}$ tromboembolii při prokazatelně účinné antikoagulační léčbě (INR 2,0-3,0), je možno zvýšit účinnost antikoagulace na hodnoty INR $3,0-3,5$.

U všech nemocných, kdy uvažujeme o použití perorálních antikoagulancií, je třeba výhody a nevýhody této léćby konzultovat s pacientem. Podstatné pro zahájení antikoagulační léčby je zhodnocení, nakolik je pacient schopen bezpečně snášet dlouhodobou antikoagulační léčbu s pravidelnými kontrolami protrombinového času.

\subsubsection{Selfmonitoring INR u fibrilace síni}

K optimalizaci antikoagulační léčby lze využít také monitorace INR pacientem (selfmonitoring). $\mathrm{V}$ tomto př́padě je třeba, aby nemocný tuto metodu preferoval, a přitom byl také schopen samostatně provádět testování INR (např. přístrojem CoaguCheck). Poučení a dobře spolupracující pacienti si v některých studiích na základě monitorace upravovali dávky warfarinu (selfmanagement). Zlepšení správné kontroly antikoagulace může pomoci také vyškolený pečovatel, např. v rámci péče „HomeCare“.

\subsubsection{Riziko tromboembolismu u paroxysmální vs. perzistující fibrilace síní}

Antitrombotická léčba je indikována u fibrilace síní paroxysmální, perzistující i permanentní. Riziko tromboembolismu je u všech typů pravděpodobně podobné. Je však známo, že pacientů s paroxysmální fibrilací bylo ve studiích s antitrombotickou léčbou méně. Přesné posouzení rizika krátkodobých atak fibrilace síní mohou přinést jen studie s kontinuální monitorací EKG u pacientů s implantovanými kardiostimulátory či defibrilátory s holterovskou funkcí. Tyto studie naznačují, že riziko tromboembolie u krátkých atak fibrilace síní (cca do 5 hodin) by mohlo být nižší.

\subsubsection{Riziko tromboembolismu u flutteru síni}

Riziko cévní mozkové př́hody spojené s flutterem síní bylo zkoumáno retrospektivně u velkého množství starších pacientů a bylo podobné jako riziko spojené s fibrilací síní. Kromě toho je potřeba vzít v úvahu koincidenci obou uvedených síňových arytmií. Prevence tromboembolismu u pacientů s prokázaným flutterem síní by se tedy měla řídit stejnými principy jako u pacientů s fibrilací síní.

\subsubsection{Zvláštní klinické situace}

\subsubsection{Perioperačni antikoagulační léčba - dočasné prerušení antikoagulace}

Před krvácivým operačním zákrokem je u nemocných s fibrilací síní často nutné ukončit antikoagulační léčbu. Většina chirurgů vyžaduje, aby hodnota INR před zákrokem 
byla $<1,5$ nebo zcela v normě. Riziko závažného krvácení by vždy mělo být porovnáváno s rizikem tromboembolie v průběhu změny antikoagulační léčby. Biologický poločas warfarinu je 36-42 hodin, antikoagulační účinek po ukončení podávání přetrvává 4-5 dní. Naopak při opětovném podání je nutno počítat s dvoudenní až třídenní latencí nástupu účinku. Warfarin lze tedy vysadit pět dnů před plánovanou operací a invazivní zákrok by měl být proveden v době poklesu INR do subterapeutických hodnot. Subterapeutická hodnota by měla trvat maximálně 48 hodin, což je období nejnižšího rizika vzniku tromboembolické komplikace. Vyvstane-li potřeba operace či jiného zákroku v době, kdy je INR stále ještě zvýšeno $(>1,5)$, lze pro jeho normalizaci zvážit perorální podání nízké dávky (1-2 mg) vitaminu $\mathrm{K}$.

Řadu menších zákroků je dnes možné provádět za nepřerušené antikoagulace. Platí to např́klad pro implantace kardiostimulátorů a defibrilátorů, u nichž je riziko krvácivých komplikací během podávání warfarinu nižší než při užívání nízkomolekulárního heparinu. Záleží však na požadavcích konkrétního pracoviště.

Pokud se přerušuje antikoagulační léčba u nemocných s fibrilací síní a mechanickou srdeční chlopní nebo s vysokým rizikem tromboembolie, je třeba vysazení antagonistů vitaminu $\mathrm{K}$ překlenout podáváním nízkomolekulárního heparinu $\mathrm{v}$ preventivní dávce, a to den po ukončení antikoagulační léčby nebo při INR pod terapeutickým rozmezím. Po provedeném krvácivém zákroku, je-li stabilní hemostáza, je vhodné večer v den zákroku nebo následující den ráno podat udržovací dávku antikoagulancia (nikoli dávku nasycovací) a u nemocných se zvýšeným rizikem tromboembolie ještě překrýt periodu subterapeutické hodnoty INR nízkomolekulárním heparinem.

\subsubsection{Perioperačni antitrombotická léčba u nemocných indikovaných k duální či trojkombinační antitrombotické léčbě}

Nemocným, u nichž je plánován chirurgický zákrok, hrozí po ukončení podávání duální či trojkombinační antitrombotické léčby vysoké riziko „in-stent“ trombózy s potenciálně fatálními důsledky (mortalita se pohybuje v rozmezí 2,5-21,4\%). Proto se u těchto vysoce rizikových nemocných s implantovaným stentem snažíme chirurgickému zákroku vyhnout (minimálně jeden měsíc u metalického stentu a jeden rok u stentů potahovaných DES). Podobně by nemocným, u nichž je operace plánovaná v průběhu nejbližších 12 měsíců, neměl být implantován potahovaný stent. ${ }^{43}$

U nemocných, kteří vyžadují provedení urgentního chirurgického zákroku, je třeba antitrombotickou léčbu individualizovat, a to na základě odhadu rizika krvácení provedeného chirurgem a rizika „in-stent“ trombózy. Při nízkém a středním riziku krvácení se u duální antitrombotické medikace doporučuje ponechat pouze podávání kyseliny acetylsalicylové a při vysokém riziku krvácení provést zákrok při úplném vysazení duální antiagregační léčby. Při vysokém riziku krvácení a subakutní urgenci operace, kdy je třeba duální protidestičkovou léčbu zcela ukončit, se sedm dnů před operací ukončí podávání kyseliny acetylsalicylové, pět dnů před operací clopidogrelu a tři dny před operací se slábnoucí protidestičkový účinek nahradí inhibitorem glykoproteinu IIb/IIIa - integrilinem nitrožilně v dávce $2 \mu \mathrm{g} / \mathrm{kg} / \mathrm{min}$. Tato infuze se $6-8$ hodin před plánovanou subakutní operací zastaví. ${ }^{44}$ Pooperačně se vrátí původní protidestičková léčba, a to co nejdříve.

U nemocného s trojkombinační antitrombotickou léčbou je třeba zvážit poměr rizika tromboembolizace a „in-stent“ trombózy. Pokud se zdá vyšší riziko „in-stent“ trombózy, přecházíme na stejnou strategii jako u duální protidestičkové léčby. Zdá-li se vyšší riziko tromboembolie, je doporučeno ukončení antitrombotické léčby týden před operací a po celou dobu tuto léčbu nahradit nízkomolekulárním heparinem $\mathrm{v}$ léčebných dávkách s posledním podáním ráno den před operací. Po operaci při nekrvácivém průběhu podáváme co nejdříve nízkomolekulární heparin se znovuzavedením trojkombinační antitrombotické léčby. Je-li operace urgentní a riziko krvácení převyšuje riziko „in-stent“ trombózy (život ohrožující traumata či vitální indikace), jediným řešením je podat destičkový koncentrát.

\subsubsection{Stabilní tepenné onemocnění}

U nemocných s fibrilací síní a stabilním tepenným onemocněním (aterosklerotické postižení mozkových, koronárních či periferních tepen), u nichž je indikována antikoagulační léčba, není vhodné přidávat léčbu antiagregační. Tato přídatná léčba již riziko cévní mozkové příhody nebo tromboembolie ani infarktu myokardu dále nesnižuje, ale naopak zvyšuje riziko krvácivých komplikací.

\subsubsection{Akutní koronární syndrom a/nebo provedená perkutánní koronární intervence}

Současná doporučení pro léčbu akutního koronárního syndromu a/nebo po provedené perkutánní koronární intervenci s implantací stentu pokládají za optimální duální antiagregační léčbu kyselinou acetylsalicylovou s clopidogrelem (čtyři týdny po implantaci kovového stentu a 6-12 měsíců po implantaci stentů potahovaných). Má-li nemocný fibrilaci síní se současně zvýšeným rizikem tromboembolie, je třeba, aby mu za těchto okolností byla podávána trojkombinační antitrombotická léčba (warfarin + kyselina acetylsalicylová + clopidogrel). Prevalence závažného krvácení při této trojkombinační léčbě je 2,6-4,6 \% během prvních 30 dnů a při medikaci po dobu 12 měsíců se zvyšuje na 7,4-10,3 \%.

Nejlepšího poměru prospěšnosti a rizika krvácení při trojkombinační léčbě je dosaženo při jejím krátkém trvání, nejlépe po dobu jednoho měsíce. Potahovaným stentům bychom se měli u nemocných indikovaných $\mathrm{k}$ antikoagulační léčbě vyhnout a trojkombinační léčba by se měla podávat jen po krátkou dobu s následnou protrahovanou kombinovanou léčbou warfarinem a jedním antiagregačním preparátem ve formě kyseliny acetylsalicylové nebo clopidogrelu (tabulky 8 a 9). 
Tab. 8 Strategie antitrombotické léčby po zavedení koronárního stentu u nemocných s $\mathrm{FS} \mathrm{s}$ více než jedním rizikovým faktorem dle stratifikace $\mathrm{CHA}_{2} \mathrm{DS}_{2}$-VASc (doporučená antikoagulační léčba) a současně s nízkým až středním rizikem krvácení dle stratifikace HAS-BLED - skóre 0-2.

\begin{tabular}{|c|c|c|}
\hline $\begin{array}{l}\text { Způsob } \\
\text { intervence }\end{array}$ & $\begin{array}{l}\text { Typ zavedeného } \\
\text { stentu }\end{array}$ & Doporučená antitrombotická léčba \\
\hline Elektivní & Metalický & $\begin{array}{l}1 \text { měsíc: trojkombinační antitrom- } \\
\text { botická léčba (warfarin s INR 2,0-2,5, } \\
\text { ASA } \leq 100 \text { mg, clopidogrel } \\
75 \text { mg/den) } \\
\text { Dlouhodobě: warfarin (INR 2,0-3,0) }\end{array}$ \\
\hline Elektivní & $\begin{array}{l}\text { Potahovaný } \\
(\mathrm{DES})^{*}\end{array}$ & $\begin{array}{l}\text { 3-6 měsíců: trojkombinační } \\
\text { antitrombotická léčba (warfarin s INR } \\
2,0-2,5, \text { ASA } \leq 100 \text { mg, clopidogrel } \\
75 \text { mg/den) } \\
\text { Do } 1 \text { roku: duální léčba } \\
\text { warfarin + clopidogrel, nebo ASA } \\
\text { ve stejném dávkování } \\
\text { Dlouhodobě: warfarin (INR } 2,0-3,0 \text { ) }\end{array}$ \\
\hline Akutní & $\begin{array}{l}\text { Metalický/pota- } \\
\text { hovaný }\end{array}$ & $\begin{array}{l}6 \text { měsíců: trojkombinační antitrom- } \\
\text { botická léčba (warfarin s INR 2,0-2,5, } \\
\text { ASA } \leq 100 \text { mg, clopidogrel } \\
75 \text { mg/den) } \\
\text { Do } 1 \text { roku: duální léčba } \\
\text { warfarin + clopidogrel, nebo ASA } \\
\text { ve stejném dávkování } \\
\text { Dlouhodobě: warfarin (INR 2,0-3,0) }\end{array}$ \\
\hline
\end{tabular}

\subsubsection{Plánovaná koronární intervence}

Při plánované koronární intervenci (PCI) by používání lékových stentů mělo být omezeno na klinické nebo ana-

\section{Tab. 9 Strategie antitrombotické léčby po zavedení koronárního stentu u nemocných s FS s více než jedním rizikovým faktorem dle stratifikace $\mathrm{CHA}_{2} \mathrm{DS}_{2}$-VASc (doporu- čená antikoagulační léčba) a současně s vysokým rizikem krvácení dle stratifikace HAS-BLED - skóre $\geq 3$}

\begin{tabular}{|c|c|c|}
\hline $\begin{array}{l}\text { Způsob } \\
\text { intervence }\end{array}$ & $\begin{array}{l}\text { Typ zavedeného } \\
\text { stentu }\end{array}$ & Doporučená antitrombotická léčba \\
\hline Elektivní & $\begin{array}{l}\text { Metalický } \\
\text { Potahované } \\
\text { stenty by se } \\
\text { neměly používat }\end{array}$ & $\begin{array}{l}2-4 \text { týdny: trojkombinační antitrom- } \\
\text { botická léčba (warfarin s INR 2,0-2,5, } \\
\text { ASA } \leq 100 \text { mg, clopidogrel } \\
75 \text { mg/den) } \\
\text { Dlouhodobě: warfarin (INR } 2,0-3,0 \text { ) }\end{array}$ \\
\hline \multirow[t]{2}{*}{ Akutní } & $\begin{array}{l}\text { Metalický } \\
\text { Potahované } \\
\text { stenty by se } \\
\text { neměly používat }\end{array}$ & $\begin{array}{l}4 \text { týdny: trojkombinační antitrom- } \\
\text { botická léčba (warfarin s INR 2,0-2,5, } \\
\text { ASA } 100 \mathrm{mg} \text {, clopidogrel } \\
75 \mathrm{mg} / \mathrm{den} \text { ) } \\
\text { Do } 1 \text { roku: duální léčba warfarin + } \\
\text { clopidogrel, nebo ASA ve stejném } \\
\text { dávkování } \\
\text { Dlouhodobě: warfarin (INR 2,0-3,0) }\end{array}$ \\
\hline & $\begin{array}{l}\text { V případě použití } \\
\text { potahovaného } \\
\text { stentu } \\
\text { (DES) }\end{array}$ & $\begin{array}{l}\text { 3-6 měsíců: trojkombinační } \\
\text { antitrombotická léčba (warfarin s INR } \\
2,0-2,5, A S A \leq 100 \text { mg, clopidogrel } \\
75 \text { mg/den) } \\
\text { Dlouhodobě: warfarin (INR } 2,0-3,0 \text { ) }\end{array}$ \\
\hline
\end{tabular}
mellitus apod., kde se ve srovnání s běžnými kovovými stenty dá čekat významný př́nos. Po čtyři týdny by měla probíhat léčba trojkombinací (antagonisté vitaminu K, kyselina acetylsalicylová a clopidogrel). Po provedení plánované koronární intervence s použitím běžných kovových stentů by pacienti s fibrilací síní a stabilním onemocněním koronárních tepen měli podstoupit dlouhodobou (12měsíční) léčbu perorálními antikoagulancii a $\mathrm{k}$ tomu bud' denní dávku 75 mg clopidogrelu, nebo alternativně denní dávku 75-100 mg kyseliny acetylsalicylové. Trojkombinační léčba (antagonisté vitaminu K, kyselina acetylsalicylová a clopidogrel) by se měla podávat minimálně jeden měsíc po zavedení běžného kovového stentu, ale při zavedení lékového stentu podstatně déle (déle než 3 měsíce u stentu sirolimového, everolimového nebo tacrolimového a nejméně 6 měsíců u stentů vylučujících paclitaxel). Poté lze navázat léčbou antagonisty vitaminu $\mathrm{K}$ kombinovanou se 75 mg clopidogrelu denně, nebo se 75-100 mg kyseliny acetylsalicylové denně.

\subsubsection{Infarkt myokardu}

U nemocných s infarktem myokardu bez elevací úseku ST je doporučena duální antiagregační léčba kyselinou acetylsalicylovou s clopidogrelem, ale u nemocných s fibrilací síní se zvýšeným rizikem tromboembolie by měla být současně také podávána léčba antikoagulační. $\mathrm{V}$ akutním stadiu se $\mathrm{v}$ jejím rámci používá především nízkomolekulární heparin. Implantace potahovaných stentů by měla být limitována stejným způsobem, jako je tomu při plánované intervenci. $V$ př́padě použití potahovaného stentu (vysoké klinické a/nebo anatomické riziko „in-stent“ trombózy) pro antitrombotickou léčbu platí stejná pravidla jako u plánované intervence.

Akutní infarkt myokardu s elevacemi úseku ST je primárně indikován k perkutánní intervenci, před níž je indikováno okamžité podání kyseliny acetylsalicylové, clopidogrelu a heparinu. Pokud je při akutním infarktu myokardu zjištěna výrazná trombotizace infarktové tepny, indikací je odsátí trombu a/nebo podání inhibitoru glykoproteinu IIb/IIIa. U nemocných, kteří jsou v té době v antikoagulační léčbě s INR > 2,0, by inhibitory glykoproteinu IIb/IIIa neměly být podány, jelikož tato kombinace antitrombotické léčby by výrazně zvýšila riziko krvácení. Po implantaci stentu by měla být podávána trojkombinační antitrombotická léčba (warfarin + kyselina acetylsalicylová + clopidogrel) s inhibitory protonové pumpy, nebo $\mathrm{s}$ blokátory $\mathrm{H}_{2}$-receptorů po dobu nejméně 3-6 měsíců. U nemocných s nízkým rizikem krvácení (HAS-BLED skóre 0-2) by na tuto terapii měla navázat léčba duální (warfarin + clopidogrel/kyselina acetylsalicylová do 12 měsíců od implantace stentu), u nemocných s vysokým rizikem krvácení (HAS-BLED skóre $\geq 3$ ) se po 3-6 měsících trojkombinační antitrombotické léčby pokračuje v antikoagulační léčbě samotným warfarinem.

Studie REDEEM ukázala, že dabigatran v maximální dávce $2 \times 150$ mg společně s duální antiagregací vedl k absolutnímu zvýšení velkých krvácivých komplikací pouze do $1 \%$ oproti placebu př̀i zachovaném klinickém účinku 
v prevenci tromboembolie, což dokládá vysokou bezpečnost této trojkombinační antitrombotické léčby nemocných po akutním infarktu myokardu.

\subsubsection{Prevence gastrointestinálního krvácení pri kombinované antitrombotické léčbě}

Výskyt krvácivých komplikací při kombinované antitrombotické léčbě je vhodné omezit doprovodnou ochranou žaludeční stěny pomocí inhibitorů protonové pumpy (IPP), blokátorů $\mathrm{H}_{2}$-receptorů nebo antacid. Inhibitory protonové pumpy mají rozdílné vlastnosti a lékové interakce. Některé $\mathrm{z}$ nich (omeprazol, lansoprazol, rabeprazol) patří k mohutným inhibitorům izoenzymu CYP 2C19, který přetváří clopidogrel na aktivní metabolit, čímž dochází ke snížení jeho účinku. V prrípadě pantoprazolu a esomeprazolu podobný účinek jednoznačně prokázán nebyl. U prasugrelu, nového př́pravku $\mathrm{z}$ řady thienopyridinů, je riziko těchto komplikací malé.

\subsubsection{Akutní cévní mozková príhoda}

Nemocní s akutní cévní mozkovou příhodou mají největší riziko tromboembolie $\mathrm{v}$ prvních dvou týdnech, ale antikoagulační léčba podaná $\mathrm{v}$ této době může vést $\mathrm{k}$ intrakraniálnímu krvácení. Pokud tito pacienti trpí fibrilací síní, měli by mít před podáním antikoagulační terapie řádně korigovanou hypertenzi. Vyšetření výpočetní tomografií či magnetickou rezonancí by mělo u cévní mozkové př́ihody vyloučit krvácivou etiologii. Při vyloučení mozkového krvácení může být antikoagulační léčba zahájena po dvou týdnech od vzniku akutní příhody.

Naopak u nemocných s fibrilací síní a přechodnou mozkovou ischemií by po vyloučení mozkového krvácení měla být antikoagulační léčba zahájena co nejdříve.

\subsubsection{Asymptomatická cévní mozková príhoda}

Cévní mozková př́hoda u pacientů s fibrilací síní je primárně embolického původu, zjištění př́ítomnosti asymptomatických vmetků v mozku by proto pomohlo určit pacienty $s$ vysokým rizikem tromboembolie. Studie mozkového snímkování (CT/MR) ukazují, že u pacientů s fibrilací síní je ve srovnání s kontrolní skupinou se sinusovým rytmem vyšší výskyt cévních mozkových prríhod. U asymptomatických pacientů nebo pacientů s prredchozí mozkovou příhodou, kteř́ jsou vystaveni vysokému riziku jejího opakování, lze ultrazvukovým transkraniálním dopplerovským vyšetřením zjistit aktivní zdroj embolického rizika.

\subsubsection{Kardioverze}

Před elektivní kardioverzí pro fibrilaci síní trvající déle než 48 hodin nebo neznámého trvání je indikována antikoagulační léčba. Na základě výsledků observačních kohortových studií by se léčba warfarinem (INR 2,0-3,0) měla podávat nejméně tři týdny před kardioverzí a ještě nejméně čtyři týdny po kardioverzi. Důvodem je riziko tromboembolie spojené s dysfunkcí levé síně nebo jejího ouška (tzv. „omráčením“ levé síně). Tromboprofylaxe se doporučuje shodně u elektrické i farmakologické kardioverze fibrilace síní.
$\mathrm{U}$ pacientů s rizikovými faktory tromboembolie je třeba pokračovat $\mathrm{v}$ léčbě warfarinem trvale - bez ohledu na to, zda se po kardioverzi sinusový rytmus obnovil.

U pacientů, u nichž je jasná doba vzniku fibrilace a její trvání nepřekračuje 48 hodin, lze kardioverzi elektivně provést př̀ nitrožilním podávání nefrakcionovaného heparinu, po němž následuje infuze nebo subkutánní podávání nízkomolekulárního heparinu. U pacientů s rizikovými faktory pro cévní mozkovou př́hodu je třeba po kardioverzi začít s perorální antikoagulační terapií a pokračovat v ní doživotně. Podávání nefrakcionovaného nebo nízkomolekulárního heparinu by mělo pokračovat, dokud se INR nedostane na terapeutickou úroveň $(2,0-3,0)$. U pacientů bez rizikových faktorů tromboembolie není perorální antikoagulace zapotřebí.

U pacientů s fibrilací síní trvající déle než 48 hodin a hemodynamickou nestabilitou je třeba provést okamžitou kardioverzi a před ní podat nefrakcionovaný nebo nízkomolekulární heparin. Po kardioverzi by se mělo začít s perorální antikoagulací a heparin by měl být podáván, dokud se INR nedostane na terapeutickou úroveň $(2,0-3,0)$. Trvání perorální antikoagulační léčby (4 týdny nebo celoživotně) bude záviset na př́tomnosti, nebo absenci rizikových faktorů mozkové příhody.

\subsubsection{Kardioverze kontrolovaná jícnovou echokardiografii}

Obvykle třítýdenní perorální antikoagulační terapii před kardioverzí lze zkrátit, pokud se při jícnové echokardiografii nezjistí žádná sraženina v levé síni ani v oušku levé síně (viz studie ACUTE). Kromě prrítomnosti sraženiny v oušku nebo jiné části levé srdeční síně toto vyšetření prokazuje také tzv. spontánní echokontrast nebo tzv. komplexní plát v průběhu aorty. Je-li k dispozici zkušený personál a náležité vybavení, doporučuje se kardioverze za pomoci jícnové echokardiografie jako alternativa $\mathrm{k}$ tř́týdenní antikoagulační terapii před kardioverzí.

Pokud jícnová echokardiografie nezjistí sraženinu v levé síni, měl by být před kardioverzí podán nefrakcionovaný nebo nízkomolekulární heparin a po ní by se v jeho podávání mělo pokračovat, dokud není s perorální antikoagulací dosaženo cílové hodnoty INR. Jestliže jícnová echokardiografie přítomnost sraženiny odhalí, je třeba zahájit léčbu warfarinem (INR 2,0-3,0) a po nejméně třech týdnech této terapie echokardiografické vyšetření zopakovat. Pokud je zjevné, že se sraženina rozpustila, lze kardioverzi provést. Po ní je však třeba doživotně pokračovat v perorální antikoagulační léčbě. Je-li sraženina stále patrná, lze namísto kontroly srdečního rytmu zvolit strategii kontroly srdeční frekvence.

\subsection{Kontrola srdečního rytmu}

\subsubsection{Kontrola rytmu versus kontrola frekvence}

Kontrola srdeční frekvence je indikována jako terapie první volby u všech nemocných vyšetřovaných pro nově vzniklou fibrilaci síní, a to nejméně do doby, než můžeme provést 
kardioverzi, popř. tam, kde je kardioverze neúspěšná nebo nevhodná. Při déletrvající fibrilaci je racionálním postupem učinit alespoň jeden pokus o nastolení sinusového rytmu, druhou možností je akceptovat fibrilaci síní jako permanentní stav s důrazem na antitrombotickou léčbu a kontrolu frekvence. Rozhodnutí učinit pokus o nastolení sinusového rytmu by mělo být založeno na tíži symptomů, př́tomnosti strukturálního onemocnění a potenciálním riziku antiarytmické léčby. I v př́padě strategie kontroly rytmu je zapotřebí v medikaci kontrolující frekvenci pokračovat do nastolení stabilního sinusového rytmu (jako prevence vysoké tepové frekvence $\mathrm{v}$ případě rekurentní fibrilace).

Kontrola frekvence je dle posledních studií (AFFIRM 2002, ${ }^{45}$ RACE 2002, ${ }^{46}$ AF-CHF $2008^{47}$ ) minimálně srovnatelný postup s kontrolou rytmu. Díky jejich vstupním kritériím (průměrný věk 70 let, nižší ejekční frakce levé komory jen u $25 \%$ nemocných) ale tyto závěry nelze přenést na všechny pacienty. Zejména pacienti mladší, významně symptomatičtí či se srdečním selháním mají výrazný prospěch ze sinusového rytmu. Antiarytmika u nich však většinou sinusový rytmus neudrží a je nutná nefarmakologická léčba. Naopak pro starší (> 70 let) a minimálně symptomatické pacienty je léčbou volby kontrola frekvence. Iniciálně zvolená strategie se však může ukázat jako neúspěšná, a poté je nutno přejít na alternativní př́stup.

\subsubsection{Akutní kontrola rytmu - konverze na sinusový rytmus}

Ataky paroxysmální fibrilace síní často končí spontánně, až u $50 \%$ se tak stane do 24 hodin. Na druhé straně časná léčba má vyšší pravděpodobnost úspěšnosti a nižší pravděpodobnost embolické komplikace. Pro zvládnutí akutní arytmie je důležitá léčba základního onemocnění, např. srdečního selhání, hypertyreózy, bronchopulmonální infekce, digitalisové intoxikace apod.

Konverze na sinusový rytmus lze dosáhnout použitím antiarytmik či elektrickým výbojem. Výběr metody záleží na posouzení výhod a nevýhod obou postupů. Elektrická kardioverze je účinnější a působí okamžitě, ale vyžaduje celkovou anestezii. U farmakoverze nelze predikovat čas verze, může se objevit proarytmický či negativně inotropní vliv antiarytmik.

Před provedením kardioverze je nutné dodržovat zásady prevence tromboembolie (viz kapitola 4.1.8).

\subsubsection{Elektrická kardioverze}

Elektrokardioverze v krátkodobé celkové anestezii je nejúčinnější a nejbezpečnější způsob restituce sinusového rytmu.

Indikace $k$ výkonu lze rozdělit na akutní a elektivní:

> akutní: u pacientů s fibrilací síní, kdy rychlou komorovou odpověd' nelze promptně potlačit farmakologicky, což vede $\mathrm{k}$ hemodynamické destabilizaci, tj. srdečnímu selhání, myokardiální ischemii, symptomatické hypotenzi; u pacientů s FS a preexcitací;

> elektivní: u pacientů s fibrilací síní jako součást léčby ke kontrole rytmu.
Před výkonem je třeba zkontrolovat, zda pacient splňuje předpoklady $\mathrm{k}$ výkonu: musí být nalačno, musí být provedeno fyzikální vyšetření, musí dát informovaný souhlas, musí u něj platit důkazy účinné antikoagulace (účinné INR), musí mít normální koncentraci iontů (kalium), musí být $\mathrm{k}$ dispozici monitorované lůžko s vybavením ke kardiopulmonální resuscitaci a intravenózní linka a krátkodobá celková anestezie by měla být vedena nejlépe anesteziologem. Elektrickou kardioverzi lze provést ambulantně, pacient by měl být monitorován minimálně tři hodiny.

Při provádění elektrické kardioverze preferujeme bifázický výboj o energii 100-150 J (druhý výboj 200 J) před výbojem monofázickým výboj (energie $200 \mathrm{~J}$, druhý výboj 360 J). ${ }^{48}$ Nutná je dostatečná příprava kůže, těsný kontakt ke snížení nitrohrudní impedance, synchronizace defibrilátoru s vlnou R. Optimální velikost elektrod pro dospělé je $8-12 \mathrm{~cm}$ $\mathrm{v}$ průměru. Anteroposteriorní umístnění elektrod (vpravo parasternálně - pod levou lopatkou) je účinnější než pozice anterolaterální (vpravo parasternálně - střední axilární čára). ${ }^{49}$ Mezi jednotlivými výboji by měl být dodržen interval alespoň tři minuty. U pacientů, jimž byl implantován kardiostimulátor či kardioverter-defibrilátor (ICD), by elektrody měly být vzdáleny nejméně $8 \mathrm{~cm}$ od baterie př́stroje, u nějž by po kardioverzi měla být zkontrolována správnost funkce. Elektrickou kardioverzi lze provést i speciální intrakardiální elektrodou, výkon se však dnes již provádí jen výjimečně.

Výskyt komplikací v souvislosti s výkonem je nízký. Riziko tromboembolie u adekvátně antikoagulovaných pacientů představuje $0-1 \%{ }^{50}$ Časté je popálení kůže. Maligní komorové arytmie (fibrilace komor, komorová tachykardie) se mohou vyskytnout obzvlášt př̀i intoxikaci digitalisem, hypokalemii, nesprávné synchronizaci výboje. Bradykardie se dostavují zejména u pacientů se sick sinus syndromem, sinusovou zástavou po výboji i s event. absencí náhradního rytmu.

Okamžitá úspěšnost se pohybuje mezi 85-95\%. K faktorům, které úspěšnost ovlivňují, patři délka trvání fibrilace před kardioverzí, věk pacienta, velikost levé síně a její dysfunkce, chlopenní vady. Rozlišujeme rekurenci fibrilace síní okamžitou (minuty po kardioverzi), časnou (během pět dnů po kardioverzi) a pozdní.

Vyšší úspěšnosti lze dosáhnout premedikací antiarytmiky ${ }^{51,52}$ Tato premedikace také snižuje výskyt časných recidiv arytmie po úspěšné kardioverzi. Vhodná jsou stejná antiarytmika, jaká jsou indikovaná k farmakologické verzi (propafenon, flecainid, amiodaron, sotalol). U pacientů se závažnějším strukturálním onemocněním srdce má $\mathrm{z}$ bezpečnostních důvodů přednost před všemi ostatními př́pravky podání amiodaronu. Vzhledem $\mathrm{k}$ riziku vzniku maligních komorových arytmií je elektrická kardioverze kontraindikována při intoxikaci digitalisem. Pokud je sérová koncentrace digoxinu v terapeutickém rozmezí, není nutno před elektivní kardioverzí terapii přerušovat.

\subsubsection{Farmakologická kardioverze}

Výhodou farmakologické verze proti elektroverzi je odpadnutí problému s anestezií. Farmakologická kardioverze by 
měla být prováděna za hospitalizace a při EKG monitorování. Úspěšnost záleží na délce trvání fibrilace - u nově vzniklé se úspěšnost verze pohybuje okolo $70 \%$, u perzistentní formy okolo $35 \%$. Antiarytmika třídy IC účinkují rychleji, ale neměla by být podávána $\mathrm{v}$ př́padě srdečního selhání či akutní ischemie. Výhodou antiarytmik III. třídy je možnost podání i při strukturálním onemocnění a oběhové nestabilitě.

Nově lze $\mathrm{k}$ verzi fibrilace síní trvající méně než sedm dnů použít nový lék vernakalant, který selektivně zpomaluje vedení a prodlužuje repolarizaci v srdečních síních. Po intravenózní aplikaci má eliminační poločas kolem dvou hodin; po jeho podání nebyly zaznamenány žádné komorové proarytmické účinky. $\mathrm{V}$ publikovaných studiích dosáhl akutní konverze na sinusový rytmus v cca $50 \%$ oproti placebu či amiodaronu, medián do konverze 12 minut, nízké procento rekurence, minimální nežádoucí účinky (nejčastěji poruchy chuti). ${ }^{53,54}$ Studie s perorálním vernakalantem probíhají. Antiarytmika doporučená pro farmakoverzi ukazuje tabulka 10.

\subsubsection{Jednorázové použití antiarytmika při obtižich (pilulka v kapse, „pill-in-the-pocket")}

U výrazně symptomatických nemocných, a přitom relativně málo častých obtížích (několikrát ročně až jednou měsíčně), lze zkusit podávání antiarytmik jen při obtížích. Byl popsán př́znivý účinek jedné dávky propafenonu (300-600 mg, zpočátku je vhodná spíše nižší dávka) a flecainidu (200-300 mg). Pacienti by neměli mít výraznější strukturální onemocnění srdce. Je nutné ověřit bezpečnost léčiva nejprve podáním ve zdravotnickém zařízení za monitorace EKG. Parenterální podání není predikcí bezpečnosti následného perorálního podání. Protože jsou popsány následné bradykardie, měl by být vyloučen syndrom chorého sinu.

\subsubsection{Dlouhodobá kontrola rytmu}

Hlavní motivací antiarytmické kontroly rytmu je snížení symptomů. Úspěšnost antiarytmik v udržení sinusového rytmu je ale nízká a klinicky úspěšnou terapií může být jen redukce obtíží (eliminace dosáhneme jen vzácně). Proarytmické a extrakardiální nežádoucí účinky jsou časté a spíše než úspěšnost je třeba mít na zřeteli bezpečnost léčby. Před podáním jakéhokoli antiarytmika je třeba zjistit prítomnost kardiovaskulárního či jiného onemocnění, které může být podkladem vzniku arytmie. Pokud je to možné, má být vyvolávající přičina upravena nebo léčena. Po první

Tab. 10 Účinná léčiva k farmakologické verzi fibrilace síní

\begin{tabular}{lll}
\hline Látka & Intravenózně & Perorálně \\
\hline Amiodaron & $\begin{array}{l}5 \mathrm{mg} / \mathrm{kg} \text { během } 60 \mathrm{~min}, \\
\text { poté } 50 \mathrm{mg} / \mathrm{h}\end{array}$ & $\begin{array}{l}1,2-1,8 \mathrm{~g} / \mathrm{den} \\
\text { do } 10 \mathrm{~g}\end{array}$ \\
\hline Propafenon & $2 \mathrm{mg} / \mathrm{kg}$ během $10-20 \mathrm{~min}$ & $450-600 \mathrm{mg}$ \\
\hline Flecainid & $2 \mathrm{mg} / \mathrm{kg}$ během $10-20 \mathrm{~min}$ & $200-300 \mathrm{mg}$ \\
\hline Vernakalant & $\begin{array}{l}3 \mathrm{mg} / \mathrm{kg} \text { i.v. během } 10 \mathrm{~min} \text {, při selhání } \\
\text { dalši dávka } 2 \mathrm{mg} / \mathrm{kg} \text { po } 15 \text { min }\end{array}$ \\
\hline
\end{tabular}

zjištěné epizodě fibrilace není obvykle nutná preventivní léčba. Podobně není prevence nutná u ojedinělých, málo symptomatických atak fibrilace síní. U těchto nemocných je také možné jednorázové podání antiarytmika (nejčastěji propafenonu) v prýpadě vzniku obtíží.

K prevenci častých a symptomatických atak fibrilace síní využíváme podobně jako u farmakoverze antiarytmika tříd IC a III (tabulka 11). U tachyarytmií se spolupodílem aktivace sympatiku podáváme beta-blokátory. K udržení sinusového rytmu u osob bez organického srdečního onemocnění je využíván propafenon, sotalol, nověji i dronedaron. U nemocných s dysfunkcí levé komory a při organickém srdečním onemocnění (zvláště ischemické chorobě srdeční) má své výhody používání amiodaronu. Antiarytmickou terapii $\mathrm{k}$ udržení sinusového rytmu u různých základních onemocněních ukazuje obrázek 1 . Amiodaron redukuje frekvenci recidiv fibrilací významněji než propafenon, sotalol a dronedaron, ale i tak se po prvním roce sledování daří udržet sinusový rytmus maximálně u 60 \% a po čtyřech letech sledování u $30 \%$ nemocných.

\subsubsection{Nová antiarytmika}

Na náš trh nově uvedený dronedaron (analog amiodaronu bez jodové skupiny) má dobrý bezpečnostní profil, jeho účinnost však nedosahuje amiodaronu, spíše se pohybuje na úrovni propafenonu a sotalolu. Byl testován $\mathrm{v}$ řadě klinických studií (tabulka 12) a jako první antiarytmikum ve studii ATHENA $^{55}$ redukoval coby primární výsledný ukazatel i mortalitu a hospitalizace z kardiovaskulárních příčin. V následné analýze studie byl v dronedaronové větvi prokázán i pokles rizika vzniku mozkové prríhody (o 34 \%, za standardní antitrombotické léčby).

Nejčastější nežádoucí účinek léčby dronedaronem představují gastrointestinální problémy (průjem, nausea, zvracení). Vzácně byla popsána plicní toxicita a př́pady akutního jaterního selhání vyžadující transplantaci.

Na základě provedených studií (hlavně studie ATHENA) byl dronedaron schválen americkou i evropskou lékovou agenturou $\mathrm{k}$ léčbě nepermanentní fibrilace síní u nemocných s ejekční frakcí levé komory > 35 \% a v doporučeních Evropské kardiologické společnosti (ESC) pro léčbu fibrilací síní ${ }^{2}$ získal díky vynikajícímu bezpečnostnímu profilu dominantní postavení v jejich antiarytmické terapii (lék první volby, mimo nemocné s těžkým srdečním selháním).

Po úspěchu dronedaronu ve studii ATHENA byla zahájena i studie PALLAS, ${ }^{56}$ a to u pacientů s permanentní

\section{Tab. 11 Účinná léčiva k udržení sinusového rytmu}

\begin{tabular}{|c|c|}
\hline Látka & Dávka \\
\hline Propafenon & 150-300 mg 3x denně \\
\hline Sotalol & $80-160$ mg 2x denně \\
\hline Flecainid & 100-200 mg 2x denně \\
\hline Amiodaron & 200 mg 1× denně \\
\hline Dronedaron & 400 mg $2 \times$ denně \\
\hline
\end{tabular}




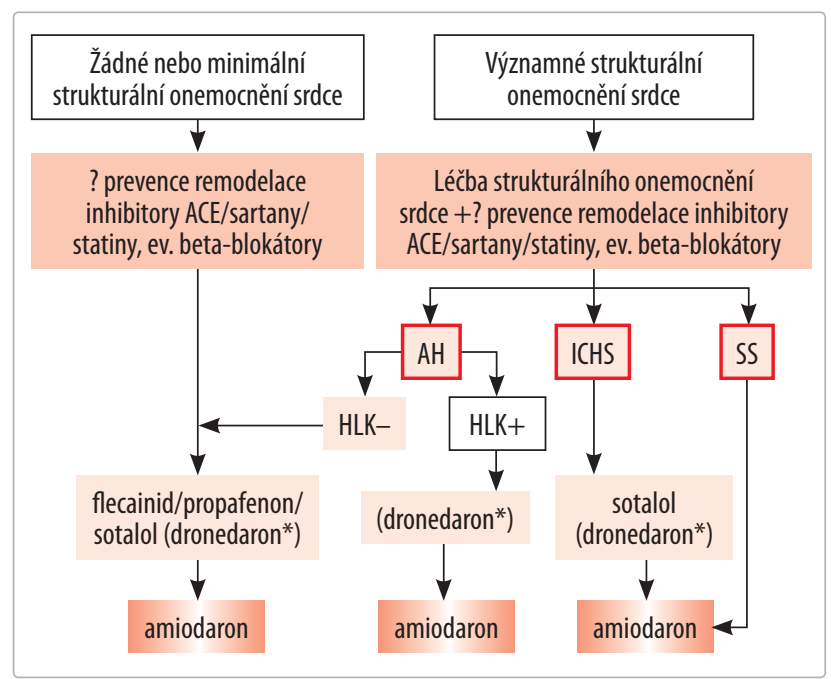

Obr. 1 Antiarytmická léčba k udržení sinusového rytmu u různých základních onemocnění

AH - arterální hypertenze; ICHS - ischemická choroba srdeční; SS - srdeční selhání; HLK - hypertrofie levé komory srdeční > 14 mm;

* U vybraných nemocných, po zvážení alternativních způsobů léčby

fibrilací a kardiovaskulárními rizikovými parametry. Tato studie byla však v červenci 2011 předčasně ukončena kvůli signifikantnímu nárůstu kardiovaskulárních příhod jak ve složených primárních ukazatelích (závažné kardiovaskulární příhody a kardiovaskulární hospitalizace nebo úmrtí), tak i ve výskytu srdečního selhání, mozkové př́hody a kardiovaskulární hospitalizace.

Tab. 12 Klinické studie s dronedaronem

\begin{tabular}{|c|c|c|}
\hline Název & Indikace & Výsledky \\
\hline DAFNE & $\begin{array}{l}\text { Ověření dávek, prevence } \\
\text { recidiv fibrilace síní } \\
\text { po kardioverzi }\end{array}$ & $\begin{array}{l}\text { Optimální dávka } \\
2 \times 400 \text { mg denně, } \\
\text { prodloužení doby } \\
\text { do recidivy fibrilace síní } \\
\text { z } 5 \text { na } 60 \text { dnů }\end{array}$ \\
\hline ERATO & $\begin{array}{l}\text { Kontrola frekvence } \\
\text { u permanentní fibrilace }\end{array}$ & $\begin{array}{l}\text { Snížení srdeční frekvence } \\
\text { během } 24 \text { h monitorace } \\
\text { o } 12 \text { tepů/min a frekvence } \\
\text { při zátěži o } 25 \text { tepů/min }\end{array}$ \\
\hline EURIDIS & $\begin{array}{l}\text { Prevence recidiv fibrilace } \\
\text { síní a flutteru }\end{array}$ & $\begin{array}{l}\text { Snížení výskytu recidiv } \\
\text { fibrilace o } 22 \%\end{array}$ \\
\hline ADONIS & $\begin{array}{l}\text { Prevence recidiv fibrilace } \\
\text { a flutteru }\end{array}$ & $\begin{array}{l}\text { Snížení výskytu recidiv } \\
\text { fibrilace o } 27 \%\end{array}$ \\
\hline ANDROMEDA & $\begin{array}{l}\text { Srdeční selhání, ejekční } \\
\text { frakce levé komory } \\
<35 \%\end{array}$ & $\begin{array}{l}\text { Předčasně ukončena, } \\
\text { zvýšená mortalita } \\
\text { v důsledku srdečního } \\
\text { selhání }\end{array}$ \\
\hline ATHENA & $\begin{array}{l}\text { Hospitalizace z kardiovas- } \\
\text { kulární přičiny či úmrtí }\end{array}$ & $\begin{array}{l}\text { Snížení rizika kardio- } \\
\text { vaskulární mortality } \\
\text { i hospitalizací o } 24 \%\end{array}$ \\
\hline DIONYSOS & Srovnání s amiodaronem & $\begin{array}{l}\text { Nižší účinnost, lepší } \\
\text { bezpečnostní profil }\end{array}$ \\
\hline PALLAS* & $\begin{array}{l}\text { Účinnost u pacientů } \\
\text { s permanentní fibrilací } \\
\text { a dalšími rizikovými } \\
\text { parametry }\end{array}$ & $\begin{array}{l}\text { Předčasně ukončena, } \\
\text { zvýšené riziko kardiovas- } \\
\text { kulárních nežádoucích } \\
\text { účinků }\end{array}$ \\
\hline
\end{tabular}

* Předběžná data
Př́nosy a rizika podávání dronedaronu byly v záŕí 2011 Evropskou lékovou agenturou přehodnoceny a použití dronedaronu bylo omezeno na nemocné s paroxysmální nebo perzistentní (po úspěšné kardioverzi) fibrilací síní, navíc po zvážení alternativních možností léčby (viz obrázek 1). Nesmí být podáván nemocným se srdečním selháním či systolickou dysfunkcí levé komory, s permanentní fibrilací (trvající $\geq 6$ měsíců) a u pacientů s projevy jaterní nebo plicní toxicity v souvislosti s eventuálním dřívějším podáváním amiodaronu. Doporučuje se monitorovat stav pacienta, při recidivě fibrilací je doporučeno zvážit přerušení terapie. Je pravděpodobné, že po podrobnějších analýzách uvedených studií bude indikace $\mathrm{k}$ podávání dronedaronu dále upřesněna.

\subsubsection{Volba antiarytmika}

Volba léku závisí také na riziku proarytmického vlivu a nežádoucích účincích antiarytmik (tabulka 13). Závažný proarytmický vliv je vzácný u pacientů s normální funkcí komor, bez bradykardie a prodloužení intervalu QT. U antiarytmik třídy IA a III (hlavně sotalolu) je možné prodloužení intervalu QT se vznikem komorových arytmií typu torsade de pointes. Délka intervalu QTc by při léčbě těmito léky neměla překročit $500 \mathrm{~ms}$. U antiarytmik třídy IC by prodloužení intervalu QRS nemělo přesáhnout $25 \%$. Při

Tab. 13 Antiarytmika ke kontrole srdečního rytmu a jejich možné nežádoucí účinky

\begin{tabular}{|c|c|c|}
\hline Antiarytmikum & Možné nežádoucí účinky & Hlavní kontraindikace \\
\hline Amiodaron & $\begin{array}{l}\text { Fotosenzitivita, dysfunkce } \\
\text { štítné žlázy, plicní } \\
\text { toxicita, polyneuropatie, } \\
\text { bradykardie, TdP (vzácně), } \\
\text { jaterní toxicita, oční } \\
\text { komplikace }\end{array}$ & $\begin{array}{l}\text { Hyperfunkce štítné žlázy } \\
\text { Přecitlivělost na jód }\end{array}$ \\
\hline Dronedaron & $\begin{array}{l}\text { Gastrointestinální } \\
\text { obtíže, bradykardie, } \\
\text { zvýšení koncentrace } \\
\text { při podávání inhibitorů } \\
\text { CYP3A4, zvýšení koncen- } \\
\text { trace digoxinu. Elevace } \\
\text { hodnoty kreatininu (bez } \\
\text { ovlivnění renálních } \\
\text { funkcí); možná jaterní } \\
\text { a plicní toxicita }\end{array}$ & $\begin{array}{l}\text { Srdeční selhání, systo- } \\
\text { lická dysfunkce levé } \\
\text { komory, permanentní } \\
\text { fibrilace síní, clearance } \\
\text { kreatininu }<30 \mathrm{mg} / \mathrm{ml}\end{array}$ \\
\hline Flecainid & $\begin{array}{l}\text { Komorová tachykardie, } \\
\text { srdeční selhání, konverze } \\
\text { do flutteru síní s rychlou } \\
\text { komorovou odpovědí }\end{array}$ & $\begin{array}{l}\text { Clearance kreatini- } \\
\text { nu }<50 \mathrm{mg} / \mathrm{ml}, \mathrm{ICHS} \text {, } \\
\text { nízká ejekční frakce levé } \\
\text { komory }\end{array}$ \\
\hline Propafenon & $\begin{array}{l}\text { Komorová tachykardie, } \\
\text { srdeční selhání, konverze } \\
\text { do flutteru síní s rychlou } \\
\text { komorovou odpovědí }\end{array}$ & $\begin{array}{l}\text { ICHS, nízká ejekční } \\
\text { frakce levé komory }\end{array}$ \\
\hline Sotalol & $\begin{array}{l}\text { TdP, srdeční selhání, } \\
\text { bradykardie, broncho- } \\
\text { spasmus }\end{array}$ & $\begin{array}{l}\text { Významná hypertrofie } \\
\text { levé komory, systolické } \\
\text { srdeční selhání, } \\
\text { preexistující prodloužení } \\
\text { intervalu QT, clearance } \\
\text { kreatininu < } 50 \text { mg/ml }\end{array}$ \\
\hline
\end{tabular}


podávání antiarytmik I. třídy by mělo být zváženo současné podávání beta-blokátorů k prevenci rychlého atrioventrikulárního vedení při vzniku flutteru síní. Ve všech případech je nutno sledovat nežádoucí účinky léčby a pravidelně monitorovat koncentrace minerálů a renální funkce (renální insuficience vede $\mathrm{k}$ akumulaci léku a predisponuje $\mathrm{k}$ proarytmii), $\mathrm{v}$ př́padě léčby amiodaronem také funkci štítné žlázy (po 3-6 měsících). Vzhledem k nově popsaným možným rizikům dronedaronu je doporučeno monitorovat srdeční, jaterní a plicní funkce. Jaterní testy (ALT) je vhodné provádět před podáním a po podání dronedaronu a dále po měsíci, po pưl roce užívání každé tři měsíce.

\subsection{Kontrola frekvence}

\subsubsection{Akutní kontrola srdeční frekvence}

Rychlá frekvence komor při fibrilaci síní může být přícinou obtíží či hemodynamické závažnosti arytmie. V těchto prrípadech je vhodné rychlé zpomalení srdeční frekvence podáním bradykardizující medikace. $\mathrm{V}$ méně závažných př́ipadech lze podat beta-blokátory nebo verapamil perorálně a zpomalit srdeční frekvenci během několika hodin. Při výraznějších obtížích je vhodná intravenózní léčba. Cílem akutního zpomalení je obvykle dosažení klidové frekvence $80-100 / \mathrm{min}$. Záleží na výchozí frekvenci, některým pacientům postačuje i mírnější zpomalení, jiní zůstávají symptomatičtí i při popsaných hodnotách.

Při pravidelné akci komor a podezření na flutter síní s akcí komor 2:1 lze ke krátkodobému zpomalení podat adenosin (12-18 mg i.v. jako rychlý bolus). Dojde k rychlému zpomalení až zablokování atrioventrikulárního převodu na několik sekund, po tuto dobu jsou síňové vlny na záznamu EKG lépe patrné (tzv. „demaskování flutteru“). Ověření diagnózy je důležité př̀ed event. indikací nefarmakologické léčby (katetrizační ablace).

Pokud je frekvence komor při fibrilaci síní naopak př́liš pomalá a pacient je symptomatický, lze dočasně podat atropin (0,5-2 mg i.v.). Za klidových podmínek však pacienti pomalejší akci většinou tolerují. Př́i výrazné bradykardii, at už se jedná o fibrilaci síní s pomalou akcí komor či úplnou AV blokádou s náhradním junkčním rytmem, bývá pak nutné zavedení dočasné komorové kardiostimulace.

Intravenózní kontrola frekvence je vhodná, pokud neindikujeme kardioverzi či medikamentózní verzi. Důvodem může být nevhodnost kardioverze zapřičiněná chybějící nebo nedostatečnou předchozí antikoagulační léčbou při nejasném trvání fibrilace či jejího trvání nad 48 hodin. Lze také kombinovat nejprve zpomalení komorové frekvence a následné provedení kardioverze. Je pak třeba mít na paměti př́padné nežádoucí účinky kombinované antiarytmické medikace.

\subsubsection{Dlouhodobá kontrola srdeční frekvence}

\subsubsection{Intenzita kontroly srdeční frekvence}

Základem léčby fibrilace síní je kontrola frekvence spolu s prevencí tromboembolických př́hod. Kontrolou frekvence léčbu začínáme. Používáme ji však i při kontrole rytmu, aby při recidivách fibrilací nebyla frekvence komor vysoká. Pokud pacient zůstává symptomatický i při méně intenzivní, př́padně intenzivní kontrole rytmu, máme zvážit kontrolu frekvence.

Stále není jasné, jaká frekvence komor by při fibrilaci síní měla být ta správná. Podle starších verzí guidelines byla doporučována klidová srdeční frekvence $60-80 /$ min a při mírné zátěži $90-115 / \mathrm{min}$. ${ }^{1,44}$ Tato doporučení však byla jen arbitrární a neopírala se o závěry studií. Nebylo také jasné, zda se máme řídit jen hodnotami zjištěnými na jednorázové křivce EKG, nebo zda máme dosažení frekvence ověřovat holterovskou monitorací EKG či ergometrií. Data ze studií porovnávajících kontrolu rytmu a kontrolu frekvence neprokázaly jasně, že by intenzivnější kontrola frekvence byla spojena $s$ nižší morbididou. Studie RACE II ${ }^{57}$ porovnávala kontrolu frekvence intenzivní (strict control) s cílem dosáhnout klidové frekvence $<80 /$ min a mírnější (lenient kontrol), kde byla cílovou metou frekvence $<110 / \mathrm{min}$. Primární kombinovaný výsledný ukazatel (úmrtí z kardiovaskulární příčiny, hospitalizace pro srdeční selhání, CMP, systémová embolizace, krvácení, život ohrožující arytmie) se při obou postupech významně nelišil (tř́letý výskyt $12,9 \%$ při méně intenzivní vs. $14,9 \%$ při intenzivní kontrole). Dosažení intenzivní kontroly však bylo podstatně obtížnější a vyžadovalo daleko častější kontroly.

Na základě těchto nálezů evropská guidelines doporučují jako výchozí postup dosažení klidové frekvence $<110 / \mathrm{min}$. Pokud obtíže nemocného přetrvávají, zejména s líčením stále rychlé akce, je vhodná intenzivnější kontrola. Ta je indikována také $\mathrm{v}$ př́ípadě, kdy dochází ke zhoršování funkce levé komory s možným podílem rychlé akce komor při fibrilaci síní. Při intenzivní kontrole frekvence je vhodné sledovat účinek léčby pomocí holterovské monitorace EKG, při trvajících obtížích během zátěže pak pomocí ergometrie.

$\mathrm{V}$ amerických dodatcích $\mathrm{k}$ doporučením ${ }^{3}$ se uvádí, že výsledky studie RACE II u pouhých 614 pacientů s dosažením 81 prríhod nemohou být dostatečné pro definitivní rozhodnutí. $\mathrm{Na}$ základě všech zatím dostupných dat se ukazuje, že dosažení hodnot klidové frekvence $<110 / \mathrm{min}$ není horším postupem než dosažení hodnot $<80 / \mathrm{min}$. Hranice $110 / \mathrm{min}$ a $80 / \mathrm{min}$ je však poměrně široká. Existují případy vzniku dysfunkce levé komory i při srdečních frekvencích kolem 110/min. U pacientů, kteří na medikaci dobře reagují, je možné snažit se o dosažení frekvence mezi oběma hodnotami, spíše $<100 / \mathrm{min}$.

\subsubsection{Farmakologická kontrola frekvence}

Pro kontrolu srdeční frekvence se využívají bradykardizující blokátory kalciových kanálů (verapamil, diltiazem), beta-blokátory, digoxin a při srdečním selhání také amiodaron. Nověji je možno využít i dronedaron, který však není vhodný pro permanentní fibrilaci síní. Výběr konkrétního přípravku a formy jeho aplikace záleží hlavně na formě fibrilace, naléhavosti snížení frekvence, komorbiditách a př́tomnosti strukturálního srdečního onemocnění (tabulka 14). U paroxysmální fibrilace síní 
Tab. 14 Antiarytmika ke kontrole srdeční frekvence při fibrilaci síní

\begin{tabular}{|c|c|c|}
\hline Látka & Intravenózní podání & Perorální podání \\
\hline \multicolumn{3}{|l|}{ Beta-blokátory } \\
\hline Metoprolol SR/XL & $2,5-5 \mathrm{mg}$ & $1 \times 100-200 \mathrm{mg}$ \\
\hline Bisoprolol & - & $1 \times 2,5-10 \mathrm{mg}$ \\
\hline Atenolol & - & $1 \times 25-100 \mathrm{mg}$ \\
\hline Esmolol & $50-200 \mu \mathrm{g} / \mathrm{kg} / \mathrm{min}$ & - \\
\hline Propranolol & $1 \mathrm{mg}$ & $2 \times 10-40 \mathrm{mg}$ \\
\hline Carvedilol & - & $2 \times 3,25-25 \mathrm{mg}$ \\
\hline \multicolumn{3}{|c|}{$\begin{array}{l}\text { Blokátory kalciových } \\
\text { kanálů }\end{array}$} \\
\hline Verapamil & $5 \mathrm{mg}$ & $2 \times 40-1 \times 360 \mathrm{mg}(\mathrm{SR})$ \\
\hline Diltiazem & - & $3 \times 60-1 \times 360 \mathrm{mg}(\mathrm{SR})$ \\
\hline \multicolumn{3}{|l|}{ Glykosidy } \\
\hline Digoxin & $0,5-1,0 \mathrm{mg}$ & $\begin{array}{l}1 \times 0,125-0,5 \mathrm{mg} \\
\text { (dle koncentrace) }\end{array}$ \\
\hline \multicolumn{3}{|l|}{ Ostatní } \\
\hline Amiodaron & $\begin{array}{l}5-50 \mathrm{mg} / \mathrm{kg} / \mathrm{h} \\
\text { (udržovací) }\end{array}$ & $1 \times 100-200 \mathrm{mg}$ \\
\hline Dronedaron & - & $2 \times 400 \mathrm{mg}$ \\
\hline
\end{tabular}

lze využít antiarytmika, která umožňují kontrolu rytmu i frekvence (sotalol, dronedaron, amiodaron). U málo aktivních pacientů lze léčbu zahájit digoxinem. Ten však nekontroluje frekvenci při zátěži. Amiodaron je pro četné nežádoucí účinky možno použít ke kontrole frekvence jen u pacientů, kde není dostatečná jiná léčba. U permanentní fibrilace síní a selhání medikace digoxinem s beta-blokátory je třeba zvážit kontrolu frekvence nefarmakologickou.

U části pacientů je frekvence komor při fibrilaci síní nevyrovnaná a střídá se rychlá a pomalá akce. V těchto př́padech bývá nezbytné doplnit antiarytmickou medikaci zavedením kardiostimulátoru. Pokud nedosáhneme účinné kontroly frekvence ani při kombinované léčbě, je zapotřebí zvážit nefarmakologickou léčbu (neselektivní katetrizační ablace AV junkce s následnou implantací kardiostimulátoru). Střídání rychlé a pomalé akce při fibrilaci síní je třeba odlišit od paroxysmální formy fibrilace síní s rychlou akcí komor a pauzami po verzi na sinusový rytmus („posttachykardickými pauzami“"). Zde je možné před implantací kardiostimulátoru zvážit selektivní katetrizační ablaci fibrilace síní.

\subsection{Upstream léčba}

\subsubsection{Teoretické předpoklady}

Ke vzniku fibrilace síní vede celá řada onemocnění a stavů, které jsou spojeny s tzv. remodelací síní, tedy jejich dilatací, strukturální přestavbou a změnou elektrofyziologických vlastností. Sama fibrilace tyto změny dále udržuje a prohlubuje. Terapie zaměřená na vyvolávající onemocnění a prevenci vzniku remodelačních změn se nazývá „upstream“ léčba. Její primárně preventivní použití může zabránit vzniku fibrilace síní, sekundární prevencí pak rozumíme použití této léčby u pacientů s již dokumentovanou arytmií, cílem je předejít dalším recidivám fibrilace síní.

\subsubsection{Inhibitory ACE a blokátory receptorů AT, pro angiotensin $\|$}

Nejvíce údajů je zatím pro prrípravky zasahující do systému renin-angiotensin-aldosteron, tedy inhibitory angiotensin-konvertujícího enzymu (ACE) a blokátory receptorů $\mathrm{AT}_{1}$ pro angiotensin II. ${ }^{58}$ Jejich mechanismem účinku je hlavně omezení vlivu angiotensinu. Ten vede ke vzniku fibrózy, hypertrofie, poruše mezibuněčného spojení, chybné funkci iontových kanálů a také k progresi zánětlivých změn.

Studie u pacientů se srdečním selháním ukazují, že podávání inhibitorů $\mathrm{ACE}$ a blokátorů receptorů $\mathrm{AT}_{1}$ pro angiotensin II vede ke snížení výskytu nově diagnostikované fibrilace síní o 30-48 \%. ${ }^{58}$ Také u hypertenze tyto př́pravky vedou $\mathrm{k}$ poklesu výskytu fibrilace síní o $25 \%$. Ve studii LIFE snížil losartan výskyt fibrilace síní více než atenolol. Mechanismem tedy není pravděpodobně jen kontrola krevního tlaku. V sekundární prevenci není vliv inhibitorů $\mathrm{ACE}$ a blokátorů receptorů $\mathrm{AT}_{1}$ pro angiotensin II tak jasný ${ }^{59} \mathrm{~V}$ několika malých studiích došlo ke snížení výskytu fibrilací síní. Tyto studie také naznačují synergistický účinek antiarytmik (např. amiodaronu) a blokátorů receptorů $\mathrm{AT}_{1}$ pro angiotensin II. Významné snížení recidiv fibrilací síní ukazují také metaanalýzy studií. V prospektivních studiích se však pozitivní vliv nepotvrdil, at’ už šlo konkrétně o hodnocení výskytu FS (studie GISSI AF, ANTIPAF), ${ }^{59}$ nebo kardiovaskulárních př́hod při FS (studie ACTIVE-I s irbesartanem). ${ }^{60}$ Vysvětlením je možné pozdní zahájení léčby u již vyjádřených remodelačních změn, kdy je $\mathrm{k}$ př́ípadnému účinku třeba delší doby, než byla lhůta sledování ve studiích.

Lze tedy shrnout, že časnou léčbou srdečního selhání a hypertenze pomocí inhibitorů ACE a blokátorů receptorů $\mathrm{AT}_{1}$ pro angiotensin II lze výskyt fibrilací síní snížit. Uvedené př́pravky jsou však v léčbě srdečního selhání a hypertenze stejně indikovány. U pacientů bez strukturálního onemocnění srdce a také v sekundární prevenci FS jsou data méně průkazná.

\subsubsection{Statiny}

Mechanismem působení je v tomto prrípadě ovlivnění zánětlivých změn v myokardu, účinek je však patrně komplexní. Několik studií prokázalo prŕíznivý vliv statinů na postoperační fibrilace síní. V ostatních případech existují jen malé studie nebo jejich metaanalýzy. Ty prokazují snížení výskytu FS, zejména u pacientů se srdečním selháním, částečně také u hypertenze a ischemické choroby srdeční. $V$ těchto případech a u postoperační fibrilace síní lze preventivní použití statinů zvážit. ${ }^{61}$ Upstream léčba s využitím inhibitorů ACE, blokátorů receptorů $\mathrm{AT}_{1}$ pro angiotensin II či statinů není indikována v primární prevenci fibrilací síní u pacientů bez kardiovaskulárního onemocnění. 


\subsubsection{Ostatní látky v upstream léčbě}

Studován byl rovněž vliv různých protizánětlivých léčiv, kortikosteroidů, vícenenasycených mastných kyselin a dalších látek, ovlivnění fibrilace síní však není konzistentněji prokázáno. Použití těchto látek v upstream léčbě fibrilace síní proto není indikováno. ${ }^{2}$

Beta-blokátory se používají v léčbě hypertenze, srdečního selhání i ischemické choroby srdeční. Ovlivněním těchto onemocnění mohou snížit výskyt fibrilací síní, jsou také vhodné ke kontrole srdeční frekvence.

\section{Nefarmakologická léčba pro fibrilaci síní}

K nefarmakologické léčbě samozřejmě patří i elektrokardioverze. Vzhledem k běžnému užívání byla uvedena společně s farmakoterapií. Dále jsou uvedeny postupy, používané ve více či méně specializovaných centrech.

\subsection{Kardiostimulace}

U pacientů po neselektivní ablaci AV junkce dochází ke vzniku atrioventrikulární blokády. Potom je nutné zajištění akce komor stimulací. Při chronické fibrilaci síní je indikována stimulace $\operatorname{VVI}(\mathrm{R})$, u paroxysmální formy pak stimulace $\operatorname{DDD}(\mathrm{R}, \mathrm{P}) .^{62,63} \mathrm{~V}$ posledním př́ípadě se však často během několika let arytmie stává chronickou, což se vysvětluje nepř́íznivým vlivem stimulace komor na udržení sinusového rytmu. U pacientů s dysfunkcí levé komory je vhodné zvážit implantaci kardiostimulátoru nebo kardioverteru-defibrilátoru s možností resynchronizace funkce levé komory. ${ }^{64}$

Implantace kardiostimulátoru je indikována rovněž při symptomatické fibrilaci síní s pomalou či nevyrovnanou akcí komor, nebo při vzniku atrioventrikulární blokády z jiných prríčin než při ablaci (podrobně viz doporučení pro implantace kardiostimulátorư $\left.{ }^{44}\right)$. Při vagově podmíněné arytmii lze před kardiostimulací zkusit disopyramid. U pacientů se sick sinus syndromem indikovaných k implantaci kardiostimulátoru je vhodnější fyziologická stimulace (DDD/R či AAI/R), protože při komorové stimulaci (VVI/R) se fibrilace síní vyskytují častěji nebo dochází k progresi paroxysmální formy do perzistující. ${ }^{62}$

Kromě klasických způsobů stimulace se zkoušely novější způsoby, a to odlišná místa a odlišné algoritmy stimulace. V prvním případě lze ke zlepšení synchronizace aktivace síní použít dvě elektrody. Ty se zavádějí do pravé síně a k ostiu koronárního sinu, prrípadně až do jeho větví, a to tak, aby bylo možné stimulovat také levou síň (tzv. biatriální stimulace). Pokud použijeme jen jednu elektrodu, lze synchronizaci síní zlepšit jejím zavedením do oblasti mezisíňového septa.

Z holterovských monitorací EKG se ukázalo, že vzniku fibrilace síní velmi často předchází zvýšená síňová ektopická aktivita či bradyarytmie. K potlačení těchto spouštěcích faktorů se používají specifické preventivní stimulační režimy. U některých přístrojů mohou být preventivní režimy doplněny o režimy terapeutické. Ty mají za cíl rychlou „overpace“ stimulací fibrilaci ukončit. To je možné za předpokladu zpomalení a stabilizace fibrilace síní v určitých fázích jejího průběhu, případně při střídání fibrilace s flutterem síní či síňovými tachykardiemi. Účinek uvedené léčby je možné ověřit opět holterovskými funkcemi př́stroje, které evidují počet, trvání a distribuci atak arytmie.

I když některé studie při použití stimulace s novými algoritmy prokázaly snížení výskytu či zátěže („burden“) fibrilací, účinek preventivních režimů je celkově pouze malý. Uvedené postupy lze použít v prrípadech indikace kardiostimulátoru z bradykardických příčin. Pro implantaci kardiostimulace jen $\mathrm{z}$ důvodů prevence fibrilací síní zatím chybějí dostatečná data.

\subsection{Implantabilní síňové kardiovertery-defibrilátory}

Úkolem síňových defibrilátorů byla detekce fibrilace síní a její verze nízkoenergetickým výbojem. Úspěšnost výbojů byla vysoká (90-95 \%), avšak i nízké energie kolem 1-3 J jsou vnímány bolestivě. $\mathrm{Z}$ těchto důvodů (kromě ekonomické náročnosti) síňové defibrilátory nikdy nedoznaly většího rozšíření.

\subsection{Katetrizační ablace AV uzlu a kardiostimulace} Katetrizační ablaci lze provést jako paliativní léčebnou metodu (ablaci AV uzlu spojenou s trvalou kardiostimulací) nebo metodu kurativní (selektivní ablaci fibrilace síní).

\subsubsection{Principy výkonu, klinický prínos}

Ablace AV uzlu s následnou kardiostimulací je paliativní metodou ke kontrole frekvence komor. Spočívá v přerušení vedení elektrického vzruchu ze síní na komory, jejichž rytmus je následně řízen kardiostimulátorem. Fibrilace síní zůstává nedotčena. Poškození AV převodu a závislost na kardiostimulátoru jsou nevratné. Účinnost ablace AV uzlu se blíží $100 \%$. Tzv. modifikace AV převodu v oblasti tzv. pomalé dráhy s cílem snížení frekvence komor při fibrilaci síní bez nutnosti implantace kardiostimulátoru je v současné době pro svou nespolehlivost opuštěna.

Při srovnání ablace AV uzlu proti antiarytmické léčbě bylo pozorováno symptomatické zlepšení ${ }^{65,66}$ a zlepšení kvality života, ${ }^{66,67}$ ale žádná studie neprokázala nebo nehodnotila zlepšení přežívání, snížení výskytu cévní mozkové příhody, počtu hospitalizací nebo zlepšení funkční třídy, funkční kapacity a ani zlepšení ejekční frakce levé komory.

Při srovnání ablace AV uzlu s biventrikulární stimulací proti antiarytmické léčbě bylo pozorováno signifikantní zlepšení ejekční frakce levé komory pouze po ablaci. ${ }^{68}$ Jiná studie ukázala, že při resynchronizační léčbě je mortalita pacientů s fibrilací síní stejná jako u pacientů se sinusovým rytmem. ${ }^{69}$ Při srovnání ablace AV uzlu s pravokomorovou stimulací proti ablaci AV uzlu s biventrikulární stimulací byla sice zjištěna nadřazenost biventrikulární stimulace, ale nikoli zásadní absolutní zlepšení ejekční frakce levé komory ${ }^{70-72} \mathrm{~V}$ jedné studii resynchronizační léčba dokonce pouze zabránila zhoršení ejekční frakce levé komory, které bylo zaznamenáno př̀i stimulaci pravé komory. ${ }^{73}$ 
Při prrímém srovnání selektivní ablace a ablace AV uzlu s biventrikulární stimulací celkem u 81 pacientů se srdečním selháním a fibrilací síní rezistentní na antiarytmika se za šest měsíců po selektivní ablaci sinusový rytmus udržoval u $81 \%$ pacientů (71 \% pacientů bez antiarytmik), zatímco po ablaci AV uzlu nejenže fibrilace síní pokračovala u všech pacientů, ale většina jejích paroxysmálních forem přešla ve formu perzistentní. Ejekční frakce levé komory se po selektivní ablaci zlepšila, zatímco po ablaci AV junkce s biventrikulární stimulací se zhoršila (rozdíl p < 0,001). U pacientů po selektivní ablaci se zlepšila i funkční kapacita a kvalita života. ${ }^{74}$

\subsubsection{Indikace ablace AV uzlu}

Ablace AV uzlu vede k nevratnému poškození atrioventrikulárního převodu a závislosti na kardiostimulaci. Proto je třeba tuto indikaci důkladně zvážit. Kromě pacientů s fibrilací síní a rychlou frekvencí komor a již zavedenou biventrikulární stimulací by se měla ablace AV uzlu zvážit jen u symptomatických pacientů rezistentních na farmakologickou kontrolu rytmu či frekvence komor, u nichž nelze předpokládat užitek ze selektivní ablace, respektive proveditelnost selektivní ablace bez zvýšené zátěže a rizik, nebo kde tato léčba selhala nebo byla odmítnuta. Stratifikace pacientů k ablaci AV junkce a implantaci kardiostimulátoru v těchto př́padech můžeme do značné míry považovat za doplněk primární stratifikace k selektivní ablaci.

Indikace $k$ ablaci AV uzlu lze doporučit u symptomatických pacientů s farmakologicky nekontrolovatelnou rychlou frekvencí komor, kteří:

> již mají naimplantovaný biventrikulární stimulační systém a u nichž pro rychlý/nepravidelný převod na komory nelze dosáhnout převládající komorové stimulace;

> mají závažné primární strukturální postižení srdce s preexistující systolickou dysfunkcí levé komory bez vyhlídky na její úpravu i při konverzi na sinusový rytmus (současně je po ablaci obvykle indikována biventrikulární stimulace);

> jsou polymorbidní se závažnými mimosrdečními nemocemi a stavy,

> jsou starší 75-80 let (individuálně lze zvážit selektivní ablaci).

Ablace AV junkce není indikována u mladších pacientů s arytmií indukovanou/zhoršenou systolickou dysfunkcí levé komory (systolická dysfunkce se rozvinula až se vznikem fibrilace síní, její závažnost se v čase mění v závislosti na střídání sinusového rytmu a fibrilací apod.). U těchto pacientů se má primárně zvážit selektivní ablace, která může vést $\mathrm{k}$ uzdravení ad integrum.

\subsection{Selektivní ablace pro fibrilaci síní}

\subsubsection{Princip účinku}

Základem ablační strategie je izolace plicních žil, jejímž cílem je trvalé přerušení výstupu ektopické aktivity z plicních žil na volnou stěnu levé síně. ${ }^{75}$ Ektopická aktivita $\mathrm{z}$ volné stěny síní se mapuje a eliminuje cíleně. ${ }^{76}$ Vzácnější ektopická aktivita $\mathrm{z}$ koronárního sinu nebo Marshallova ligamenta může být řešena izolací koronárního sinu, aktivita $\mathrm{z}$ horní duté žíly její izolací. ${ }^{77-79}$ Lokalizované reentry okruhy mohou být při běžící fibrilaci síní odstraněny tzv. na elektrogramu založenou ablací (cílenou na místa s frakcionovanou aktivitu, nejrychlejší aktivitou nebo lokálním aktivačním gradientem), ${ }^{80}$ respektive cílenou ablací po organizaci do síňové tachykardie. ${ }^{81}$ Velké makro-reentry okruhy se přerušují lineárními lézemi. ${ }^{82}$ Jako přínosná se považuje současná ablace nervových ganglií a plexů, lokalizovaných blízko plicních žil, takže je často automaticky součástí obkružujících ablačních lézí. ${ }^{83}$

\subsubsection{Provedení výkonu a technologie}

K ablaci se používají různé mapovací i ablační technologie. Přístup do levé srdeční síně se řeší transseptálně. Ablace se nejčastěji provádí řiditelným katetrem pro mapování a aplikaci radiofrekvenční energie bod po bodu. Kromě aplikace energie bod po bodu se používají i cirkulární nebo polocirkulární katetry, umožňující aplikaci najednou kolem ústí plicní žíly. Dále se v praxi uplatňují balonové katetry s využitím mražení nebo laseru nebo cirkulární/sítové katetry s použitím radiofrekvenční energie s cílem dosáhnout izolace plicních žil jednou nebo několika málo aplikacemi ablační energie. Ablace bod po bodu je použitelná na všechny zdroje. Balonové a cirkulární katetry narážejí na anatomickou různorodost plicních žil, doposud nepřekonaly účinnost izolace plicních žil metodou bod po bodu a nelze je použít na zdroje fibrilace síní mimo plicní žíly. Ablace fibrilace síní lze provést s prostou skiaskopickou navigací nebo pomocí 3D mapovacích systémů, jejichž obrazy lze integrovat s 3D obrazy síní získanými z CT, MR, případně rotační angiografie. Provedení ablace může být facilitováno použitím intrakardiálního ultrazvuku. Katétr může být naváděn přímo rukou operatéra nebo pomocí dálkové navigace magnetickým polem nebo robotickou rukou s řiditelným pouzdrem na katetry.

\subsubsection{Cílové momenty ablačního výkonu}

Zatím neexistují technologie spolehlivě zobrazující vznik myokardiální léze v průběhu ablace. Individuální léze se v praxi hodnotí podle redukce nebo vymizení lokálního elektrického potenciálu. Izolace plicních žil se nejpřesněji hodnotí jejich mapováním uvnitř ústí plicních žil pomocí cirkulárního katetru. ${ }^{84}$ Někteří autoři je nahrazují mapováním voltážovým. ${ }^{85}$ Úplná izolace koronárního sinu se hodnotí multipolárním katetrem. Lineární léze přerušující velké makro-reentry okruhy (léze ve stropě levé síně, na laterálním mitrálním isthmu, respektive na kavo-trikuspidálním isthmu) se hodnotí podle změny aktivace síní a tzv. diferenční stimulace. ${ }^{82}$ Dalšími cílovými momenty celého výkonu může být ukončení fibrilace síní a obnovení sinusového rytmu (zvláště u perzistentní formy FS) ${ }^{81,86}$ nebo dosažení nevyvolatelnosti arytmie rychlou stimulací síní, isoprenalinem nebo adenosinem. 


\subsubsection{Dlouhodobé udržení sinusového rytmu}

Klinická účinnost ablace fibrilací síní je příznivá. Většina recidiv se projeví v průběhu prvních týdnů až měsíců, často $\mathrm{v}$ souvislosti s pozdějším vysazením antiarytmik. Pozdní recidivy jsou méně časté ${ }^{87}$ Je přirozený rozdíl mezi vysokou účinností referovanou renomovanými centry (> $90 \%$ ) a běžnou klinickou praxí ${ }^{88}$ Podle celosvětového registru je celková klinická úspěšnost ablace paroxysmální, perzistentní a dlouhodobé perzistentní fibrilace síní $84 \%$, $75 \%$ a $71 \%$, respektive bez užívání antiarytmik $75 \%, 65 \%$ a $63 \% .^{88}$ Ačkoli je úspěšnost ablace perzistentní FS nižší, centra, která uplatňují komplexní ablační strategie, referují úspěšnost srovnatelnou s ablací paroxysmální FS. K takovému výsledku je nutná rozsáhlejší ablační strategie a častější opakované ablace pro reziduální zdroje fibrilací síní.

Příčinou recidiv fibrilace síní nebo síňové tachykardie je nedokončení izolace nebo zotavení izolační linie kolem arytmogenní plicní žíly, neodstranění/zotavení lokalizovaného zdroje mimo plicní žíly, nepřerušení/zotavení aktivního reentry okruhu, resp. vznik nového aktivního reentry okruhu nedokonalou ablační lézí (proarytmický účinek) a snad i přirozená progrese substrátu. Všechny zdroje časných nebo pozdních recidiv lze odstranit opakovanou ablací.

\subsubsection{Klinický prínos ablace fibrilace síní}

Účinnost ablace při udržení sinusového rytmu je signifikantně vyšší než při léčbě antiarytmiky. ${ }^{89-92}$ Kvalita života se po ablaci fibrilace síní zvyšuje a její zlepšení je signifikantně vyšší než při léčbě antiarytmiky. ${ }^{91-92}$ Toto zlepšení se jeví stabilní i dlouhodobě v závislosti na udržení sinusového rytmu. ${ }^{93}$ Kvalita života se zlepšuje po úspěšné ablaci paroxysmální i perzistentní fibrilace síní. ${ }^{94}$

Velikost síní se po ablaci konzistentně zmenšuje $\mathrm{v}$ důsledku jizvení i reverzní remodelace. Na rozdíl od některých chirurgických ablací dochází po katetrizační ablaci k zachování nebo zlepšení funkce levé síně, a to i při použití extenzivní ablace. ${ }^{95}$

Ablace fibrilace síní u pacientů se systolickou dysfunkcí je konzistentně spojena s jejím zlepšením nebo úplnou úpravou. Systolická dysfunkce se upravuje nejen u pacientů s rychlou, ale i tzv. přiměřenou frekvencí komor. ${ }^{96}$

Některé recentní studie ukazují redukci incidence tromboembolických př́hod po ablaci i po ukončení antikoagulace $u$ většiny pacientů na méně než $0,5 \% /$ rok, tedy na úroveň populace bez fibrilace síní. ${ }^{97-99}$ Interpretace těchto výsledků musí být opatrná, nebot ablaci podstupují pacienti se všeobecně nižším než průměrným přirozeným rizikem tromboembolie. Jedna nedávná studie ukazuje, že pacienti léčení ablací mají dlouhodobě podobný výskyt úmrtí, cévní mozkové prŕhody a demence jako pacienti bez fibrilace síní. ${ }^{100}$ Zatím neexistují přímá data o vlivu ablace fibrilace síní na mortalitu. Výsledky prvních studií dávajících odpověd' na tuto otázku lze očekávat nejdříve v roce 2015.

\subsubsection{Komplikace výkonu}

Komplikace výkonu se vyskytují asi v 5 \% případů. Většinou jde o lokální cévní komplikace v místě vpichu. Jsou shrnuty v recentním celosvětovém registru. ${ }^{88}$ Nejčastější závažnou komplikací je srdeční tamponáda a embolická cévní mozková prŕhoda nebo transitorní ischemická ataka (v naprosté většině $s$ frustním průběhem bez rezidua), incidence obou je kolem 1,2 \%. Nejzávažnější komplikací, jejíž průběh je většinou fatální, je vznik atrio-ezofageální píštěle. Její riziko je podle registru 0,04 \%. Komplikace se projevuje v odstupu několika dnů po ablaci a začíná septickým stavem. Dříve častější stenózu plicních žil lze v současné době při použití širších periantrálních (místo ostiálních) lézí prakticky vyloučit. Paréza bráničního nervu se může vyskytnout zvláště při balonkové ablaci, konkrétně pravostranných plicních žil, naštěstí je většinou přechodná. Mortalita v souvislosti s ablací fibrilace síní je výrazně $<0,1 \%$. Za komplikaci ablace pro fibrilace síní se někdy považuje i vznik nových síňových tachykardií, které vyžadují další ablaci. Bez ohledu na jejich mechanismus a příčinu (proarytmický účinek nebo odkrytí preexistujícího reziduálního zdroje) lze na tyto síňové tachykardie místo jako na komplikaci pohlížet i jako na určitý „mezistupeň“ k obnově sinusového rytmu.

\subsubsection{Indikace selektivní ablace}

Indikace selektivní ablace fibrilace síní jsou založeny na symptomech, účinnosti a toleranci antiarytmik, systolické funkci levé komory, pracovním zařazení, individuálních aktivitách a postoji pacienta (obrázek 2). Ablace je sice účinnější než antiarytmická léčba, ale vzhledem $\mathrm{k}$ vysoké prevalenci fibrilace síní a také ekonomickým limitům není tento výkon dostupný pro všechny způsobilé pacienty. Existují jen omezená data, která by podle vstupních charakteristik předpovídala vyšší skupinovou rentabilitu ablace. A konečně není znám přínos $\mathrm{z}$ úspěšné ablace $\mathrm{v}$ horizontu mnoha let až desetiletí ani vliv na mortalitu. U pacientů s perzistentní FS bývá nutná složitější ablační strategie zasahující i mimo plicní žíly a pacienti musejí být připraveni

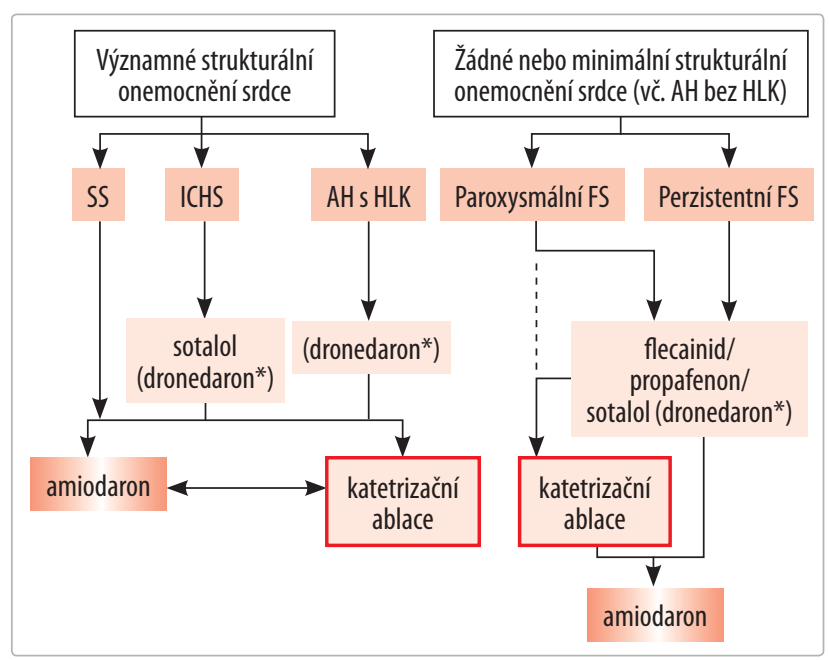

Obr. 2 Postavení katetrizační ablace v léčbě fibrilace síní

Ablace je indikována u symptomatických nemocných po selhání alespoň jednoho antiarytmika. U pacientů s paroxysmální fibrilací síní lze v odůvodněných prípadech zvážit ablaci i jako metodu první volby před podáním antiarytmika. AH - arterální hypertenze; ICHS - ischemická choroba srdeční; SS - srdeční selhání; HLK - hypertrofie levé komory srdeční > 14 mm.

* U vybraných nemocných, po zvážení alternativních způsobů léčby 
na častější opakované ablace. Arbitrární rozdělení perzistentní FS na podskupinu dlouhodobě perzistentní FS podle nepřetržitého trvání fibrilace déle než jeden rok neodráží spolehlivě individuální arytmogenní substrát či nezbytný rozsah ablace. ${ }^{99}$

A) Ablace je indikována u pacientů, u nichž lze očekávat užitek $\mathrm{z}$ výkonu (obrázek 3). Jde o pacienty:

1. mladší (<70-75 let, je vždy třeba individuální př́stup) s paroxysmální FS, symptomatické, bez významných komorbidit, bez významného primárního strukturálního postižení srdce, zvláště při neúčinné antiarytmické léčbě;

2. mladší s perzistentní FS, symptomatické bez významných komorbidit, bez významného primárního strukturálního postižení srdce, zvláště př̀i neúčinné antiarytmické léčbě; zkušenosti a úroveň důkazů je zde nižší než u paroxysmální FS;

3. se systolickou dysfunkcí levé komory, kde je předpoklad zlepšení funkce levé komory po obnově sinusového rytmu;

4. mladší, aktivní, u nichž lze ablaci zvážit i před podáním antiarytmik;

5. u nichž byl před ablací pro fibrilaci síní nebo během výkonu zachycen flutter síní I. typu, je indikována současná ablace kavo-trikuspidálního isthmu; výkon lze provést i bez dokumentace flutteru síní I. typu.

B) Naopak primárně rezervovaný postoj k selektivní ablaci je na místě u pacientů, u nichž lze očekávat minimální nebo žádný užitek $\mathrm{z}$ ablace, a naopak horší toleranci a vyšší riziko výkonu. Individuální zvážení je možné, zvláště při rozhodování podle věku a prítomnosti primárního strukturálního postižení srdce. Jde o pacienty:

1. polymorbidní se závažnými mimosrdečními nemocemi;

2. se závažným primárním strukturálním postižením srdcem s preexistující systolickou dysfunkcí levé komory bez vyhlídky na její úpravu, respektive bez vyhlídky na zlepšení kvality života nebo ukonční podávání warfarinu při sinusovém rytmu;

3. starší ( $\geq 70-75$ let, je vždy třeba individuální přístup);

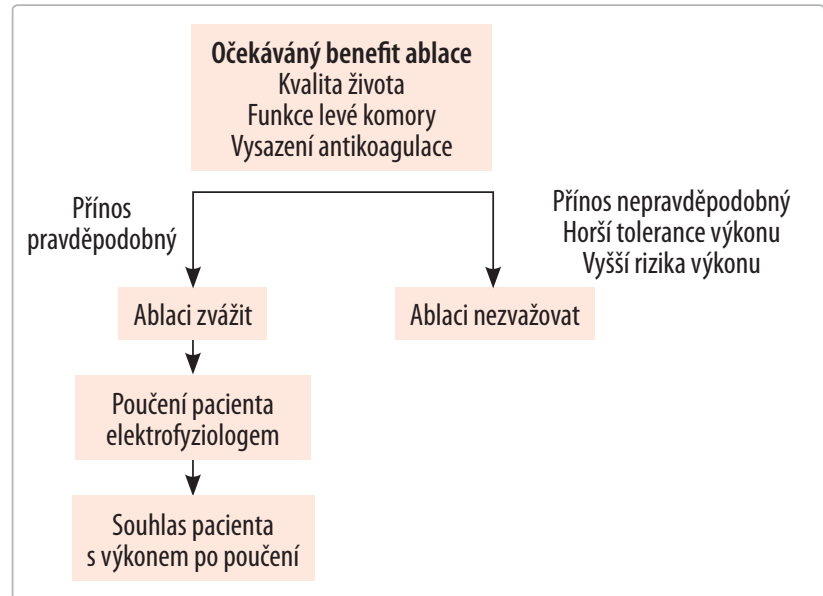

Obr. 3 Rozhodování o indikaci k selektivní katetrizační ablaci pro fibrilaci síní
4. relativně starší s perzistentní fibrilací síní bez primárního strukturálního postižení srdce, ale asymptomatické, bez systolické dysfunkce levé komory, dobře tolerující antikoagulační léčbu a současně nemotivované $\mathrm{k}$ ablaci.

Pacient by o výkonu měl být podrobně poučen včetně rizik, obvyklých klinických výsledků a možném opakování výkonu, a to nejlépe v centru, které ablace provádí. Následné rozhodnutí o indikaci výkonu pak respektuje názor poučeného pacienta. Rozsah strukturálních změn, arytmogenního substrátu a nezbytný rozsah ablační strategie (od pouhé izolace plicních žil po lineární léze a ablaci dalších zdrojů fibrilací) může být stanoven až $\mathrm{v}$ průběhu samotného výkonu.

\subsubsection{Sledování po ablaci}

Před výkonem se antagonisté vitaminu K většinou vysazují a nahrazují nízkomolekulárním heparinem (low molecular weight heparin, LMWH), i když některá centra při výkonu antikoagulaci nepřerušují. Při samotném výkonu se aplikuje nefrakcionovaný heparin intravenózně a ideálně se udržuje hodnota aktivovaného koagulačního času kolem 300-400 s. Po ablaci je nutné pokračovat v antikoagulační léčbě minimálně 2-6 měsíců podle charakteru arytmie a typu výkonu. Potom záleží na rizikové stratifikaci tromboembolie. Zatím převládá názor, že u pacientů s $\mathrm{CHADS}_{2}$ skóre $\geq 2$ se má trvalá antikoagulace spíše ponechat. Data o tomto postupu nejsou jednotná a $\mathrm{v}$ praxi ani všeobecně respektovaná (viz odstavec 5.4.5), jedná se o prríklon $\mathrm{k}$ bezpečnější variantě.

Antiarytmika mohou být vysazena nebo mohou zůstat ponechána ke stabilizaci časného období hojení a reverzní remodelace. Př́ípadné recidivy arytmie, zvláště po ablaci perzistentní fibrilace síní, je vhodné co nejdříve ukončit např. elektrickou kardioverzí a proces reverzní remodelace takto podpořit. Období prvních tří měsíců po ablaci se většinou v klinických studiích nehodnotí (tzv. blanking perioda). Př́padnou opakovanou ablaci je až na výjimky vhodné plánovat ne dříve než po uplynutí prvních 3-6 měsíců po předchozí ablaci.

\subsection{Chirurgická léčba fibrilace síní}

\subsection{1 Úvod}

Fibrilace síní je nezávislým rizikovým faktorem, který negativně ovlivňuje výsledek srdeční operace; je spojena s vyšší perioperační úmrtností, zejména u pacientů s ejekční frakcí levé komory $\geq 40 \%$. Ačkoli není jisté, nakolik fibrilace síní (nezávisle na dalších faktorech) ovlivňuje dlouhodobé přežití pacientů po operaci srdce, obnovení sinusového rytmu výsledky zlepšuje. ${ }^{101}$ Ve srovnání s katetrizačními metodami lze chirurgickou ablací snadno dosáhnout úplné elektrické izolace s dostatečně transmurálními lézemi. V indikovaných př́padech, kde se nepředpokládá obnovení sinusového rytmu, lze snesením ouška levé síně ovlivnit riziko následné tromboembolie. 


\subsubsection{Operace pro fibrilaci síní}

Počátky operací pro fibrilaci síní byly paliativní, podobně jako počátky ablací (ablace AV uzlu). Izolovala se fibrilující levá sín od zbytku srdce se sinusovým rytmem. Základem moderní kurativní léčby bylo však až zavedení tzv. „operace MAZE“102 (bludiště). Cílem bylo narušení mnohočetných reentry okruhů u fibrilace síní. Při výkonu se provádí izolace plicních žil metodou řezů a opětovného sešití („cut and sew“), postupuje se k mitrálnímu prstenci, oušku pravé a levé síně srdeční a koronárnímu sinu. Dlouhodobá účinnost takto provedené operace MAZE je velmi vysoká; až 75-95\% nemocných nemá po dobu 15 let klinicky ověřenou recidivu fibrilace síní. U pacientů s postižením mitrální chlopně nedokáže samotná operace chlopně snížit riziko fibrilace síní ani mozkové tromboembolické př́hody. Souběžné provedení operace MAZE vede $\mathrm{k}$ výsledkům srovnatelným s výsledky u pacientů, kteří podstoupí operaci mitrální chlopně a mají sinusový rytmus. Operace MAZE také příznivě ovlivňuje obnovení kontraktility levé síně.

Limitem výkonu MAZE je jeho náročnost a zatížení rizikem významných komplikací. Proto došlo k modifikaci operace s nahrazením nebo doplněním chirurgických řezů aplikací různých forem energie.

\subsubsection{Technika výkonu a používané energie}

Kromě samotné operace MAZE se dnes provádí spíše perioperační ablace, kde je vzniku lézí dosaženo vytvářením ablačních linií místo incizí. Jde o rychlejší a méně invazivní postup. Výkony jsou prováděny především ve spojení s dalším chirurgickým zákrokem (operace mitrální chlopně, aortální chlopně, aortokoronární bypass), kde prodlouží vlastní operaci jen o 10-20 minut. Výhodou je dobrý př́stup $\mathrm{k}$ síním na otevřeném hrudníku a možnost vizuální kontroly lézí.

Pokud perioperační ablace není spojena s kardiochirurgickým zákrokem, lze výkon provádět na běžícím srdci a miniinvazivně ( $t j$. thorakoskopicky nebo s podporou robotizace). Podobně jako u endovasálních ablací, i u paroxysmální fibrilace síní většinou postačuje izolace plicních žil, u perzistující fibrilace bývá třeba komplexnějšího výkonu.

K vytváření lézí lze použít různé energetické zdroje, nejčastěji kryoenergii, radiofrekvenci (unipolární, bipolární), ultrasonografii (HIFU, soustředěný ultrazvuk vysoké intenzity), mikrovlny nebo laser. ${ }^{103,104}$ Použité energie lze kombinovat, při operaci MAZE III jsou incize doplňovány vytvářením linií kryoenergií. Aplikace lze provádět endokardiálně či epikardiálně, případně postupy také kombinovat. K vytváření lézí lze používat různé sondy, které často umožní docílit dlouhé léze jednou aplikací. Také tvar a počet ablačních linií se liší. Výkony mohou zahrnovat i pravou síň, základem jsou však linie v levé síni. Zatím prakticky neexistují studie, které by srovnávaly výsledky při použití jednotlivých technik. Transmuralita a kompletnost lézí je většinou nižší než při incizích a opětovném sešití.

Úspěšnost perioperačních ablací závisí na řadě faktorů. Kromě samotné techniky výkonu a zkušenostech centra je to hlavně délka trvání fibrilace a velikost levé síně. Negativní vliv na úspěšnost zákroku může mít také vyšší věk pacienta, arteriální hypertenze a spánková apnoe. ${ }^{105}$

\subsubsection{Indikace chirurgické léčby}

Pokud je u pacienta s fibrilací síní indikován kardiochirurgický výkon, doplnění o perioperační ablaci lze provést většinou snadno. Proto by měla být perioperační ablace zvážena u naprosté většiny pacientư s paroxysmální i perzistující fibrilací síní. Je však třeba vzít v úvahu doprovodná onemocnění, trvání fibrilace, velikost síní a další faktory, které ovlivňují úspěšnost výkonu. ${ }^{106}$ Při výrazném zvětšení levé síně a mnohaleté anamnéze fibrilace bývá remodelace síní velmi pokročilá a úspěšnost perioperačních ablací je nízká.

Indikace $\mathrm{k}$ provádění zákroku pro fibrilace síní jako samostatného výkonu (minithorakotomie, thorakoskopie) není zdaleka tak jasně přijímána. Záleží většinou na zkušenosti daného pracoviště, a to jak v oblasti chirurgického řešení fibrilace, tak v oblasti provádění endovasálních ablací. Záleží i na typu fibrilace síní. Obecně je pro ni ve světě zatím mnohem častěji prováděna endovasální ablace.

\subsubsection{Sledování po chirurgické ablaci}

Po chirurgické ablaci probíhá reverzní remodelace síní, která je často komplikována časnou rekurencí FS a výskytem i jiných arytmií. Postup by měl být obecně podobný jako po endovasálních katetrizačních ablacích. Nejméně po dobu tří měsíců je nutno podávat současně antiarytmika a provádět účinnou antikoagulaci. Ukončení antikoagulační léčby u pacientů s vyšším rizikem tromboembolismu (skóre $\mathrm{CHADS}_{2} \geq 2$ ) často není možné. Po třech měsících je vhodné echokardiografické vyšetření s posouzením srdeční hemodynamiky.

Podobně jako komplexní endovasální ablace pro fibrilaci síní provází vznik síňových tachykardií, i perioperační ablace jsou zatíženy tímto rizikem. Nedostatečným sledováním lze výskyt pooperačních recidiv fibrilací síní i síňových tachykardií přehlédnout. Arytmie lze pak řešit kontrolou rytmu či frekvence antiarytmiky, někdy je však třeba spolupráce $s$ pracovištěm se zkušenostmi v provádění endovasálních ablací.

\subsection{Nefarmakologické metody prevence mozkových príhod}

Nejčastějším místem vzniku sraženin při fibrilaci síní je ouško levé síně. Uzavření ouška tedy může u pacientů s FS omezit formování sraženin a snížit výskyt cévních mozkových příhod. K uzávěru ouška se používají různé typů okluderů (Watchman, Amplatzer, Sentre Heart), které se zavádějí punkčně přes femorální žílu a následně transseptálně do ouška. Často je zatím uzávěr ouška nedokonalý. Dat o př́nosu okluderů v porovnání s léčbou antitrombotiky je málo, výkony se zatím provádějí v rámci klinických studií. Největší zkušenosti jsou spojeny s okluderem Watchman. Studie PROTECT AF ${ }^{107,108}$ u 707 pacientů s fibrilací síní při jeho použití prokázala non-inferioritu účinku (parametrem byl kompozitní výskyt cévní mozkové př́ihody, úmrtí 
v důsledku kardiovaskulárního onemocnění a systémové embolie) v porovnání s warfarinem. Ve skupině, která podstoupila zákrok, byl iniciálně vyšší výskyt nežádoucích př́hod. Kromě okluderů se zkouší také podvaz ouška (thorakoskopicky nebo z minithorakotomie, případně i přes perikardiální punkci). Výhodou je možnost kombinace s ablací pro fibrilaci síní.

Žádný z uvedených postupů však dosud nebyl schválen pro rutinní klinické použití. K zavedení okluderu by měli být vhodní pacienti s vysokým rizikem tromboembolismu i krvácivých komplikací, př́ípadně s intolerancí či kontraindikací antitrombotické léčby.

Pokud je indikován kardiochirurgický výkon, většina pracovišt současně provádí excizi levého ouška. Některá pracoviště provádějí pouze podvaz ouška, jiná nechávají ouško zcela intaktní, což odůvodňují významem mechanické funkce ouška. Pokud je podvaz ouška nekompletní, může být výskyt tromboembolických komplikací vyšší. Celkově však přínos chirurgických zákroků na oušku z hlediska ovlivnění tromboembolických př́hod stále není spolehlivě zhodnocen.

\section{Literatura}

1. Fuster V, Ryden LE, Cannom DS, et al. ACC/AHA/ESC 2006 guidelines for the management of patients with atrial fibrillation: full text. A report of the American College of Cardiology/American Heart Association Task Force on practice guidelines and the European Society of Cardiology Committee for practice guidelines. Europace 2006;8:651-645.

2. Camm AJ, Kirchhof P, Lip GY, et al. Guidelines for the management of atrial fibrillation: the Task Force for the Management of Atrial Fibrillation of the European Society of Cardiology (ESC). Eur Heart J 2010;31:2369-2429.

3. Wann LS, Curtis AB, Craig TJ, et al. ACCF/AHA/HRS focused update on the management of patients with atrial fibrillation (updating the 2006 Guideline). Circulation 2011;123:104-123.

4. Wann LS, Curtis AB, Ellenbogen KA, ACCF/AHA/HRS focused update on the management of patients with atrial fibrillation (updating on dabigatran). J Am Coll Cardiol 2011;15 [Epub ahead of print].

5. Čihák R, Heinc P. Doporučení pro léčbu pacientů s fibrilací síní. Cor Vasa 2004;46:K67-K77.

6. Kirchhof $\mathrm{P}$, Auricchio A, Bax J, et al. Outcome parameters for trials in atrial fibrillation: executive summary. Eur Heart J 2007;28(22):2803-2817.

7. Jahangir $A$, Lee V, Friedman PA, et al. Long-term progression and outcomes with aging in patients with lone atrial fibrillation: a 30-year follow-up study. Circulation 2007;115:3050-3056.

8. De Vos CB, Pison L, Pisters R, et al. Progression from paroxysmal to persistent atrial fibrillation clinical correlates and prognosis. J Am Coll Cardiol 2010;55:725-731.

9. Nieuwlaat R, Capucci A, Camm AJ, et al. Atrial fibrillation management: a prospective survey in ESC member countries: the EuroHeart Survey on Atrial Fibrillation. Eur Heart J 2005;26:2422-2434.

10. Nabauer M, Gerth A, Limbourg T, Schneider S, et al. The Registry of the German Competence NETwork on Atrial Fibrillation: patient characteristics and initial management. Europace 2009;11:423-434.

11. Kostin S, Klein G, Szalay Z, et al. Structural correlate of atrial fibrillation in human patients. Cardiovasc Res 2002;54:361-379.

12. Boldt A, Wetzel U, Lauschke J, et al. Fibrosis in the left atrial tissue of patients with atrial fibrillation with and without underlying mitral valve disease. Heart 2004;90:400-405.

13. Spach MS, Boineau JP. Microfibrosis produces electrical load variation due to loss of side-to-side cell connections: A major mechanism of structural heart disease arrhythmias. Pacing Clin Electrophysiol 1997;20:397-413.

14. Li D, Fareh S, Leung TK, et al. Promotion of atrial fibrillation by heart failure in dogs: Atrial remodeling of a different sort. Circulation 1999;100: 87-95.
15. Ausma J, Wijfels $M$, Thone $F$, et al. Structural changes of atrial myocardium due to sustained atrial fibrillation in the goat. Circulation 1997;96:3157-3163.

16. Goette A, Staack T, Rocken C, et al. Increased expression of extracellular signal-regulated kinase and angiotensin-converting enzyme in human atria during atrial fibrillation. J Am Coll Cardiol 2000;35:1669-1677.

17. Li D, Shinagawa K, Pang L, et al. Effects of angiotensin-converting enzyme inhibition on the development of atrial fibrillation substrate in dogs with ventricular tachypacing-induced congestive heart failure. Circulation 2001;104:2608-2614.

18. Kumagai $\mathrm{K}$, Nakashima $\mathrm{H}$, Urata $\mathrm{H}$, et al. Effects of angiotensin II type 1 receptor antagonist on electrical and structural remodeling in atrial fibrillation. J Am Coll Cardiol 2003;41:2197-2204.

19. Boldt A, Scholl A, Garbade J, et al. ACE-inhibitor treatment attenuates atrial structural remodeling in patients with lone chronic atrial fibrillation. Basic Res Cardiol 2006;101:261-267.

20. Fiala $M$, Wichterle $D$, Chovančík J, et al. Left atrial voltage during atrial fibrillation in paroxysmal and persistent atrial fibrillation patients. Pacing Clin Electrophysiol 2010;33:541-548.

21. Kuppahally SS, Akoum N, Burgon NS, et al. Left atrial strain and strain rate in patients with paroxysmal and persistent atrial fibrillation. Relationship to left atrial structural remodeling detected by delayed-enhancement MRI. Circ Cardiovasc Imaging 2010;3:231-239.

22. Go AS, Hylek EM, Phillips KA, et al. Prevalence of diagnosed atrial fibrillation in adults: national implications for rhythm management and stroke prevention: the AnTicoagulation and Risk Factors in Atrial Fibrillation (ATRIA) Study. JAMA 2001;285:2370-2375.

23. Heeringa J, van der Kuip DA, Hofman A, et al. Prevalence, incidence and lifetime risk of atrial fibrillation: the Rotterdam study. Eur Heart J 2006;27:949-953.

24. Lloyd-Jones DM, Wang TJ, Leip EP, et al. Lifetime risk for development of atrial fibrillation: the Framingham Heart Study. Circulation 2004;1 10:1042-1046.

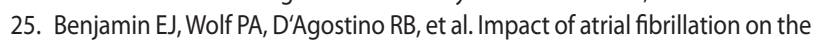
risk of death: the Framingham Heart Study. Circulation 1998;98:946-952.

26. Wolf PA, Abbott RD, Kannel WB. Atrial fibrillation as an independent risk factor for stroke: the Framingham Study. Stroke 1991;22:983-988.

27. Friberg L, Hammar N, Rosenqvist M. Stroke in paroxysmal atrial fibrillation: report from the Stockholm Cohort of Atrial Fibrillation. Eur Heart J 2010;31:967-975.

28. Frost $L$, Engholm $G$, Johnsen $S$, et al. Incident thromboembolism in the aorta and the renal, mesenteric, pelvic, and extremity arteries after discharge from the hospital with a diagnosis of atrial fibrillation. Arch Intern Med 2001;161:272-276.

29. Knecht $S$, Oelschläger C, Duning $T$, et al. Atrial fibrillation in stroke-free patients is associated with memory impairment and hippocampal atrophy. Eur Heart J 2008;29:2125-2132.

30. Thrall G, Lane D, Carroll D, et al. Quality of life in patients with atrial fibrillation: a systematic review. Am J Med 2006;119:448.e1-19.

31. Bulková V, Fiala M, Chovančík J, et al. Analýza nákladů na léčbu u pacientů s fibrilací síní v České republice. Cor Vasa 2008;5023-27.

32. Lip GY, Lim HS. Atrial fibrillation and stroke prevention. Lancet Neurol 2007;6:981-993.

33. Hughes M, Lip GY. Guideline Development Group. National Clinical Guideline for Management of Atrial Fibrillation in Primary and Secondary Care, National Institute for Health and Clinical Excellence. Stroke and thromboembolism in atrial fibrillation: a systematic review of stroke risk factors, risk stratification schema and cost effectiveness data. Thromb Haemost 2008;99:295-304.

34. Stroke in AF working group. Independent predictors of stroke in patients with atrial fibrillation: a systematic review. Neurology 2007;69:546-554.

35. Lip GY, Nieuwlaat R, Pisters R, et al. Refining clinical risk stratification for predicting stroke and thromboembolism in atrial fibrillation using a novel risk factor-based approach: the Euro Heart Survey on atrial fibrillation. Chest 2010;137:263-272.

36. Schmitt J, Duray G, Gersh BJ, et al. Atrial fibrillation in acute myocardial infarction: a systematic review of the incidence, clinical features and prognostic implications. Eur Heart J 2009;30:1038-1045.

37. Mant J, Hobbs FD, Fletcher $\mathrm{K}$, et al. Warfarin versus aspirin for stroke prevention in an elderly community population with atrial fibrillation (the Birmingham Atrial Fibrillation Treatment of the Aged Study, BAFTA): a randomised controlled trial. Lancet 2007;370:493-503. 
38. Connolly S, Pogue J, Hart R, et al. Clopidogrel plus aspirin versus ora anticoagulation for atrial fibrillation in the Atrial fibrillation Clopidogre Trial with Irbesartan for prevention of Vascular Events (ACTIVE W): a randomised controlled trial. Lancet 2006;367:1903-1912.

39. Connolly SJ, Pogue J, Hart RG, et al. Effect of clopidogrel added to aspirin in patients with atrial fibrillation. N Engl J Med 2009;360:2066-2078.

40. Connoly SJ, Ezekowitz MD, Yusuf S, et al. Dabigatran versus warfarin in patients with atrial fibrillation. N Engl J Med 2009;361:1139-1151.

41. Patel MR, Mahafey KW, Garg J, et al.; for the ROCKET AF Investigators. Rivaroxaban versus warfarin in nonvalvular atrial fibrillation. N Engl J Med 2011;365:883-891.

42. Granger CHB, Alexander JH, McMurray JV, et al., for the ARISTOTLE Committees and Investigators. Apixaban versus warfarin in patients with atrial fibrillation. Engl J Med 2011;365:981-992.

43. Grines $\mathrm{CL}$, Bonow $\mathrm{RO}$, Casey $\mathrm{DE}$, et al. Prevention of premature discontinuation of dual antiplatelet therapy in patients with coronary artery stents: A science advisory from the American Heart Association, American College of Cardiology, Society for Cardiovascular Angiography and Interventions, American College of Surgeons, and American Dental Association, with representation from the American College of Physicians. J Am Coll Cardiol 2007;49:734-739.

44. Brilakis ES, Banerjee S, Berger PB. Perioperative management of patients with coronary stents. J Am Coll Cardiol 2007;49:2145-2150.

45. The Atrial Fibrillation Follow-up Investigation of Rhythm Management (AFFIRM) Investigators. A comparison of rate control and rhythm control in patients with atrial fibrillation. N Engl J Med 2002;347:1825-1833.

46. Van Gelder IC, Hagens VE, Bosker HA, et al. A comparison of rate control and rhythm control in patients with recurrent atrial fibrillation. $\mathrm{N}$ Engl $J$ Med 2002;347:1834-1840.

47. Roy D, Talajic M, Nattel S, et al. Rhythm control versus rate control for atrial fibrillation and heart failure. N Engl J Med 2008;358:2667-2677.

48. Page RL, Kerber RE, Russell JK, et al. Biphasic versus monophasic shock waveform for conversion of atrial fibrillation: the results of an international randomized double-blind multicenter trial. J Am Coll Cardiol 2002;39:1956-1963.

49. Kirchhof $\mathrm{P}$, Eckardt L, Loh $\mathrm{P}$, et al. Anterior-posterior versus anterior-lateral electrode positions for external cardioversion of atrial fibrillation: a randomised trial. Lancet 2002;360:1275-1279.

50. Arnold AZ, Mick MJ, Mazurek RP, et al. Role of prophylactic anticoagulation for direct current cardioversion in patients with atrial fibrillation or atrial flutter. J Am Coll Cardiol 1992;19:851-855.

51. Manios EG, Mavrakis HE, Kanoupakis EM, et al. Effects of amiodarone and diltiazem on persistent atrial fibrillation conversion and recurrence rates: a randomized controlled study. Cardiovasc Drugs Ther 2003;17:31-39.

52. Bianconi L, Mennuni M, Lukic V, et al. Effects of oral propafenone administration before electrical cardioversion of chronic atrial fibrillation: a placebo-controlled study. J Am Coll Cardiol 1996;28:700-706.

53. Roy D, Pratt CM, Torp-Pedersen C, et al. Vernakalant hydrochloride for the rapid conversion of the atrial fibrillation: a phase 3 , randomized placebo-controlled trial. Circulation 2008;117:1518-1525.

54. Camm AJ, Capucci A, Hohnloser $\mathrm{SH}$, et al. A randomized active-controlled study comparing the efficacy and safety of vernakalant to amiodaron in recent-onset atrial fibrillation. J Am Coll Cardiol 2011;57:313-321.

55. Hohnloser SH, Crijns HJ, van Eickels $\mathrm{M}$, et al. Effect of dronedarone on cardiovascular events in atrial fibrillation. N Engl J Med 2009;360:668-678.

56. Connolly SJ, Camm AJ, Halperin JL, for the PALLAS Investigators. Dronedarone in high-risk permanent atrial fibrillation. N Engl J Med 2011 (10.1056/ NEJMoa1109867)

57. Van Gelder IC, Groenveld HF, Crijns HJ, et al. Lenient versus strict rate control in patients with atrial fibrillation. N Engl J Med 2010;362:1363-1373.

58. Zhang Y, Zhang P, MuY, et al. The role of renin-angiotensin blockade therapy in prevention of atrial fibrillation: a meta-analysis of randomized controlled trials. Clin Pharmacol Ther 2010 Sept 1 (Epub ahead of print).

59. Disertori M, Latini R, Barlera S, Franzosi MG, et al. Valsartan for prevention of recurrent atrial fibrillation. N Engl J Med 2009;360:1606-1617.

60. ACTIVE I Investigators, Yusuf S, Healey JS, Pogue J, et al. Irbesartan in patients with atrial fibrillation. N Engl J Med 2011;364:928-938.

61. Savelieva I, Camm AJ. Statins and polyunsaturated fatty acids for treatment of atrial fibrillation. Nat Clin Pract Cardiovasc Med 2008;5:30-41.

62. Epstein AE, DiMarco JP, Ellenbogen KA, et al. ACC/AHA/HRS guidelines for device based therapy of cardiac rhythm abnormatilies. J Am Coll Cardiol 2008;51:el-62.
63. Táborský $M$, et al. Zásady pro implantace kardiostimulátorů, implantabilních kardioverterů-defibrilátorů a systémů pro srdeční desynchronizační léčbu. Cor Vasa 2009;51(9):602-618.

64. Dickstein K, Vardas PE, Auricchio A, et al. 2010 focused update of ESC Guidelines on device therapy in heart failure: an update of the 2008 ESC Guidelines for the diagnosis and treatment of acute and chronic heart failure and the 2007 ESC Guidelines for cardiac and resynchronization therapy. Developed with the special contribution of the Heart Failure Association and the European Heart Rhythm Association. Eur J Heart Fail 2010;12:1143-1153.

65. Brignole $M$, Gianfranchi $L$, Menozzi $C$, et al. Influence of atrioventricular junction radiofrequency ablation in patients with chronic atrial fibrillation and flutter on quality of life and cardiac performance. J Am Coll Cardiol 1994;74:242-246.

66. Marshall HJ, Harris Zl, Griffith MJ, et al. Prospective randomized study of ablation and pacing versus medical therapy for paroxysmal atrial fibrillation: effects of pacing mode and mode-switch algorithm. Circulation 1999;97:1587-1592.

67. Weerasooryia $R$, Davis $M$, Powel A, et al. The Australian Intervention Randomized Control of Rate in Atrial Fibrillation Trial (AIRCRAFT). J Am Coll Cardiol 2003;41:1697-1702.

68. Gasparini M, Auricchio A, Regoli F, et al. Four-year efficacy of cardiac resynchronization therapy on exercise tolerance and disease progression. J Am Coll Cardiol 2006; 48:734-43.

69. Gasparini M, Auricchio A, Metra M, et al. Long-term survival in patients undergoing cardiac resynchronization therapy: the importance of performing atrio-ventricular junction ablation in patients with permanent atrial fibrillation. Eur Heart J 2008;29:1644-1652.

70. Linde $C$, Leclercq $C$, Rex $S$, et al. Long-term benefits of biventricular pacing in congestive heart failure: results from the Multisite Stimulation in Cardiomyopathy (MUSTIC) study. J Am Coll Cardiol 2002;40:111-118.

71. Leclercq C, Walker S, Linde C, et al. Comparative effects of permanent biventricular and right atrial pacing in heart failure patients with chronic atrial fibrillation. Eur Heart J 2002;23:1780-1787.

72. Brignole M, Gammage M, Puggioni $E$, et al. Comparative assessment of right, left, and biventricular pacing in patients with permanent atrial fibrillation. Eur Heart J 2005;26:712-722.

73. Doshi RN, Daoud EG, Fellows C, et al. Left ventricular-based cardiac stimulation post AV nodal ablation evaluation (the PAVE study). J Cardiovasc Electrophysiol 2005;16:1160-1165.

74. Khan $M N$, Jais $P$, Cummings JE, et al. Pulmonary-vein isolation for atrial fibrillation with heart failure. N Engl J M 2008;359:1778-1785.

75. Haïssaguerre $M$, Jaïs $P$, Shah $D C$, et al. Spontaneous initiation of atrial fibrillation by ectopic beats originating in the pulmonary veins. $\mathrm{N}$ Engl J Med 1998;339:659-666.

76. Haïsssaguerre $M$, Hocini $M$, Sanders $P$, et al. Localized sources maintaining atrial fibrillation organized by prior ablation. Circulation 2006;113:616-625.

77. Sanders $P_{\text {, Jaïs }}$, Hocini $M$, et al. Electrical disconnection of the coronary sinus by radiofrequency catheter ablation to isolate a trigger of atrial fibrillation. J Cardiovasc Electrophysiol 2004;15:364-368.

78. Hwang C, Wu TJ, Doshi RN, et al. Vein of Marshall cannulation for the analysis of electrical activity in patients with focal atrial fibrillation. Circulation 2000;101:1503-1505.

79. Chen PS, Wu TS, Hwang $C$, et al. Thoracic veins and the mechanism of nonparoxysmal atrial fibrillation. Cardiovasc Res 2002;54:295-301.

80. Nademanee K, McKenzie J, Kosar E, et al. A new approach for catheter ablation of atrial fibrillation: Mapping and the electrophysiologic substrate. J Am Coll Cardiol 2004:43:2044-2053.

81. Haïsssaguerre M, Sanders $P$, Hocini M, et al. Catheter ablation of long-lasting persistent atrial fibrillation: critical structures for termination. J Cardiovasc Electrophysiol 2005;16:1125-1137.

82. Jaïs $\mathrm{P}$, Hocini $\mathrm{M}, \mathrm{Hsu} \mathrm{LI}$, et al. Techniques and results of linear ablation at the mitral isthmus. Circulation 2004;110:2996-3002.

83. Scherlag BJ, Yamanashi W, Patel U, et al. Autonomically induced conversion of pulmonary vein focal firing into atrial fibrillation. J Am Coll Cardiol 2005;45:1878-1886

84. Haïssaguerre $M$, Jaïs $P$, Shah $D C$, et al. Electrophysiological endpoint for catheter ablation of atrial fibrillation initiated from multiple pulmonary venous foci. Circulation 2000;101:1409-1417.

85. Pappone C, Rosanio S, Oreto G, et al. Circumferential radiofrequency ablation of pulmonary vein ostia: a new anatomic approach for curing atrial fibrillation. Circulation 2000;102:2619-2628. 
86. Fiala $M$, Chovančík J, Nevřalová $R$, et al. Termination of long-lasting persistent versus short-lasting persistent and paroxysmal atrial fibrillation by ablation. Pacing Clin Electrophysiol 2008;31:985-997.

87. Tzou WS, Marchlinski FE, Zado ES, et al. Long-term outcome after successful catheter ablation of atrial fibrillation. Circ Arrhythm Electrophysiol 2010;3:237-242.

88. Cappato R, Calkins H, Chen SA, et al. Updated worldwide survey on the methods, efficacy, and safety of catheter ablation for human atrial fibrillation. Circulation 2010;3:32-38.

89. Wazni OM, Marrouche NF, Martin DO, et al. Radiofrequency ablation vs antiarrhythmic drugs as first-line treatment of symptomatic atrial fibrillation: a randomized trial. JAMA 2005:293:2634-2640.

90. Pappone C, Augello G, Sala S, et al. A randomized trial of circumferential pulmonary vein ablation versus antiarrhythmic drug therapy in paroxysmal atril fibrillation. The APAF study. J Am Coll Cardiol 2006;48:2340-2347.

91. Jais $P$, Cauchemez B, et al. Catheter ablation versus antiarrhythmic drugs for atrial fibrillation: the A4 study. Circulation 2008;118:2498-2505.

92. Wilber DJ, Pappone C, Neuzil P, et al. Comparison of antiarrhythmic drug therapy and radiofrequency catheter ablation in patients with paroxysmal atrial fibrillation: A randomized controlled trial. JAMA 2010;303:333-340.

93. Wokhlu A, Monahan $\mathrm{KH}$, Hodge DO, et al. Long-term quality of life after ablation of atrial fibrillation: the impact of recurrence symptom relief, and placebo effect. J Am Coll Cardiol 2010;55:2309-2316.

94. Bulková V, Fiala $M$, Haman $L$, et al. Zlepšení kvality života po ablaci dlouhodobě perzistentní versus paroxysmální fibrilace síní: výsledky dvouletého sledování. Vnitř Lék 2011, přijato k publikaci.

95. Takahashi Y, O'Neill MD, Hocini M, et al. Effects of stepwise ablation of chronic atrial fibrillation on atrial electrical and mechanical properties. J Am Coll Cardiol 2007;49:1306-1314.

96. Hsu LF, Jaïs P, Sanders $P$, et al. Catheter ablation for atrial fibrillation in congestive heart failure. N Engl J Med 2004;351:2373-2383.

97. Oral H, Chugh A, Özaydin M, et al. Risk of thromboembolic events after percutaneous left atrial radiofrequency ablation of atrial fibrillation. Circulation 2006;114:759-765.

98. Nademanee K, Schwab MC, Kosar EM, et al. Clinical outcomes of catheter ablation for high-risk patients with atrial fibrillation. J Am Coll Cardiol 2008:51:843-849.
99. Themistoclakis S, Corrado A, Marchlinski FE, et al. The risk of thromboembolism and need for oral anticoagulation after successful atrial fibrillation ablation. J Am Coll Cardiol 2010;55:735-743.

100. Bunch TJ, Crandall BG, Weiss $P$, et al. Patients treated with catheter ablation for atrial fibrillation have long-term rates of death, stroke, and dementia similar to patients without atrial fibrillation. J Cardiovasc Electrophysiol 2011;22:839-845.

101. Kernis SJ, Nkomo VT, Messika-Zeitoun D, et al. Atrial fibrillation after surgical correction of mitral regurgitation in sinus rhythm: incidence, outcome and determinants Circulation 2004;110:2320-2325.

102. Cox JL, Boineau JP, Schusler RB, et al. Five-year experience with the Maze procedure for atrial fibrillation. Ann Thoorac Surg 1993;56:814-824.

103. Melo J, Adragao P, Neves J, et al. Endocardial and epicardial radiofrequency ablation in the treatment of atrial fibrillation with a new intra-operative device Eur J Cardiothorac Surg 2000;18:182-186.

104. Ghavidel AA, Javadpour $H$, Shafiee $M$, et al. Cryoablation for surgical treatment of chronic atrial fibrillation combined with mitral valve surgery: a clinical observation. Eur J Cardiothorac Surg 2008;33: 1043-1048.

105. Calkins H, Brugada J, Packer DL, et al. EHRA/ECAS Expert consensus statement on catheter and srugical ablation of atrial fibrillation: Recommendation for personnel, policy, procedures and follow up: a report of the HRS task force oncatheter and surgical ablation of atrial fibrillation developed in partnership with the EHRA and ECAS in collaboration with the ACC, AHA. Europace 2007;9:335-379.

106. Pagé $P$, CCS Atrial Fibrillation Guidelines Committee. Canadian Cardiovascular Society Atrial Fibrillation Guidelines 2010: Surgical Therapy. Can J Cardiol 2011;27:67-73.

107. Holmes DR, Reddy VY, Turi ZG, et al. Percutaneous closure of the left atrial appendage versus warfarin therapy for prevention of stroke in patients with atrial fibrillation: a randomised noninferiority trial. Lancet 2009;374:534-542.

108. Reddy VY, Holmes D, Doshi SK, et al. Safety of percutaneous left atrial appendage closure: results from the Watchman Left Atrial Appendage System for Embolic Protection in Patients with AF (PROTECT AF) clinical trial and the Continued Access Registry. Circulation 2011;123: 417-424. 